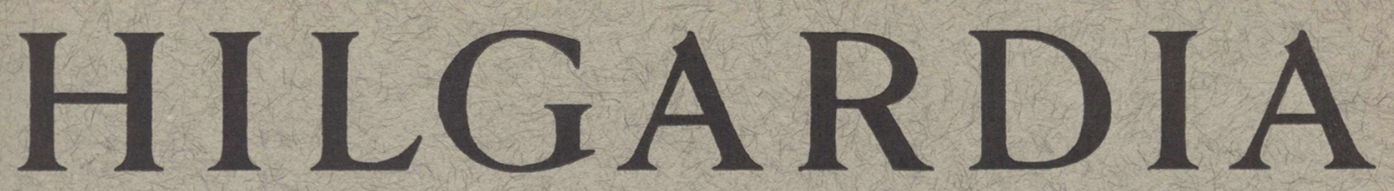

A Journal of Agricultural Science Published by the California Agricultural Experiment Station

$\begin{array}{lll}\text { VOLUME } 20 & \text { OCTOBER, } 1950 & \text { NUMBER } 13\end{array}$

\title{
STUDIES ON SEARCHING CAPACITY OF THE LARVAE OF THREE PREDATORS OF THE CITRUS RED MITE
}

\author{
CHARLES A. FLESCHNER
}




\section{CONTENTS}

Procedure -233

The experimental universes . . . . . . . . . . . . . . . 233

Type-I universe . . . . . . . . . . . . . . . . . . 234

Type-II universe . . . . . . . . . . . . . . . . . . 234

Type-III universe. . . . . . . . . . . . . . . . . 235

Type-IV universe . . . . . . . . . . . . . . . . . . 235

Procurement and handling of prey . . . . . . . . . . . . 236

Restriction of prey to preferred areas . . . . . . . . . . . 237

Restriction of prey to least-preferred areas . . . . . . . . . 237

Procurement and handling of predators . . . . . . . . . . . 237

Correlated movements of predator and prey studied independently . . 239

Phototropic and geotropic responses of the citrus red mite . . . 239

Phototropic and geotropic responses of the predator larvae . . . 241

Summary of results . . . . . . . . . . . . . . . . . . 244

Reactions of predator species in presence of prey . . . . . . . . 245

Searching ability . . . . . . . . . . . . . . . . 245

Ability to perceive prey . . . . . . . . . . . . . . 245

Area effectively searched . . . . . . . . . . . . . . . 251

Ability to search in crevices and through protective coverings . . 253

Feeding ability . . . . . . . . . . . . . . . . . . . 254

Maximum feeding tests . . . . . . . . . . . . . . 254

Ability to consume prey quickly . . . . . . . . . . . . 254

Minimum feeding tests . . . . . . . . . . . . . . . 255

Competition with other species of predators . . . . . . . . 257

Cannibalism ..... . . . . . . . . . . . . 258

Ability of predator species to survive . . . . . . . . . . . . 258

Ability to survive a critical period . . . . . . . . . . . 258

Ability to survive at a low prey density . . . . . . . . . . . 259

Field observations . . . . . . . . . . . . . . . . . . . 263

Summary . . . . . . . . . . . . . . . . . . . . . . 263

Literature cited . . . . . . . . . . . . . . 265 


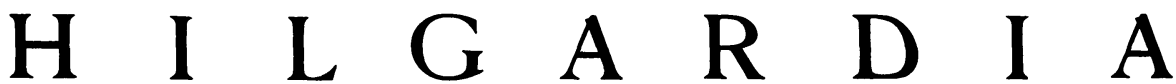

A Journal of Agricultural Science Published by

the California Agricultural Experiment Station

VoL. 20

OCTOBER, 1950

No. 13

\section{STUDIES ON SEARCHING CAPACITY OF THE LARVAE OF THREE PREDATORS OF THE CITRUS RED MITE ${ }^{1,2}$}

\section{CHARLES A. FLESCHNER}

The CITRus RED Mite, Paratetranychus citri (McGregor), probably native to China, was originally recorded from orange in Florida in 1885. It now occurs in all states in which citrus is grown, with the possible exception of Arizona. There are no known parasites of this pest, but it is attacked by a number of predaceous insects and mites. A comprehensive account of the life histories and habits of the citrus red mite and its natural enemies in California has been given by Quayle (1912). ${ }^{4}$

Three predators of the citrus red mite commonly found in California are the red mite destroyer, Stethorus picipes Casey ; the green lacewing, Chrysopa californica Coquillett; and the dusty wing, Conwentzia hageni Banks. The laboratory studies reported here were undertaken to gain a better understanding of various interesting factors which determine the searching capacity of the larval stages of these predaceous species.

\section{PROCEDURE}

Experiments were carried on in a basement room at the University of California Citrus Experiment Station, Riverside. This room was maintained at a constant temperature of $80^{\circ} \pm 2^{\circ} \mathrm{F}$, and at a relative humidity of $50 \pm 2$ per cent. Illumination was entirely artificial.

\section{The Experimental Universes}

The prey and each species of predator were tested separately in four types of experimental universe: Type-I, characterized by conditions of uniform light and topography ; Type-II, varied light and uniform topography; TypeIII, uniform light and varied topography; and Type-IV, varied light and topography. The predators were then tested in each environment with prey present in its preferred locations, and again with the prey present in its least-preferred locations.

\footnotetext{
${ }^{1}$ Received for publication March 2, 1950.

${ }^{2}$ Paper No. 639, University of California Citrus Experiment Station, Riverside, California.

${ }^{3}$ Assistant Entomologist in the Experiment Station.

"See "Literature Cited" for complete data on citations, referred to in text by name of author and date of publication.
} 
Since all the experimental animals were very sensitive to light, it was necessary to utilize a cubicle, the walls of which absorbed light, so that the reactions of the subjects would not be affected by reflected light rays. This cubicle (fig. 1) was an uncovered black wooden box, 44 inches long, 26 inches wide, and 20 inches deep. The front of the box was replaced by a black cloth which could be manipulated to permit easy handling of the subjects tested. Experimental subjects were restricted to each test environment by

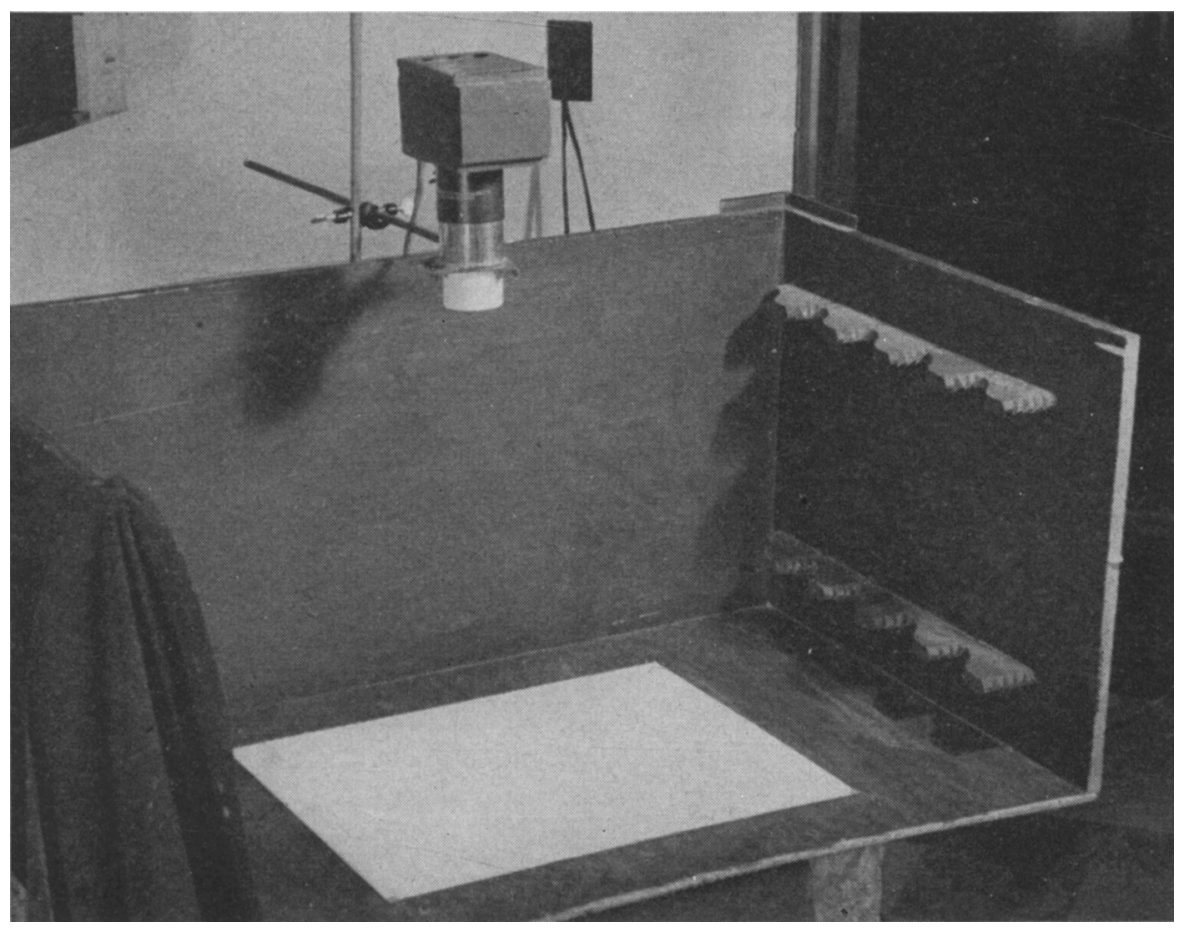

Fig. 1. Cubicle, with microscope lamp in place to form a Type-II universe (varied light and uniform topography).

the use of a high-resistance wire connected to the electric light circuit and secured around the border of the universe, a barrier developed by Flanders (1945). The searched surfaces of the universes consisted of rag bond paper (sheets 17 by 22 inches in size, 1/4-inch quadrille-ruled).

Type-I Universe. For a universe having uniform light and topography, a full sheet of the 17- by 22-inch paper was laid flat on the bottom of the cubicle, directly under a source of light consisting of three 40-watt, 48-inch daylight Mazda fluorescent tubes, 7 feet above the paper. This arrangement gave a fairly uniform light intensity, which measured 28 foot-candles at the center but diminished slightly toward the borders of the universe.

Type-II Universe. For a universe having varied light and uniform topography, the topography was the same as that used in the Type-I universe, but the source of light was a Bausch and Lomb microscope lamp containing 
a clear 100-watt globe, securely fixed at a height of 28 inches above the floor of the cubicle. This "spotlight" provided a circular area of light 15 inches in diameter, with a maximum intensity of 600 foot-candles, which diminished to between 1 and 0 foot-candles at the border of the illuminated area.

Type-III Universe. For a universe having uniform light and varied topography, the light arrangement was the same as that for the Type-I universe, but the floor of the universe was reduced to 11 by 17 inches, and on it, at

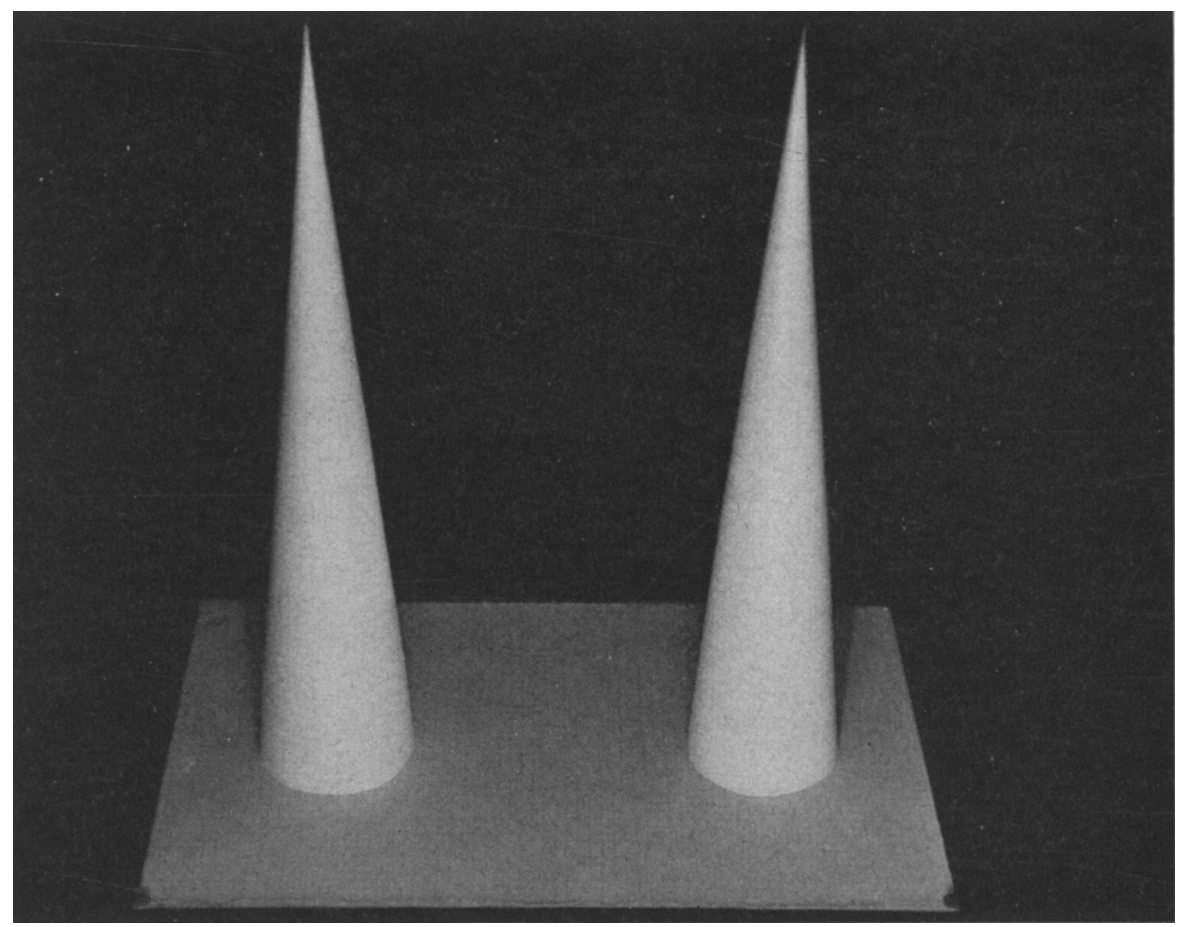

Fig. 2. Type-III universe (uniform light, varied topography).

each end, was placed a cone $3 \frac{1}{2}$ inches in diameter and $163 / 4$ inches high (fig. 2). These cones were so constructed that the total surface area of this (Type-III) universe was approximately the same as that of the uniform (Type-I) universe.

Type-IV Universe. For a universe having varied light and topography, one of the two cones was illuminated by the spotlight placed directly above it, the other cone being outside the circular lighted area. The side of the latter cone which was toward the lighted area was dimly illuminated by reflected light. The opposite side was much darker, and the area of the floor of the universe in the shadow of this cone was dark.

The experimental animal was judged to be positively or negatively phototropic according to whether it remained the greater portion of its searching period within or outside the border of the illuminated circular area. 


\section{Procurement and Handling of Prey}

All the citrus red mites used in these experiments were field-collected. Miteinfested twigs were clipped from eitrus trees and brought into the laboratory, where they were held in cold storage until needed. Large numbers of mites

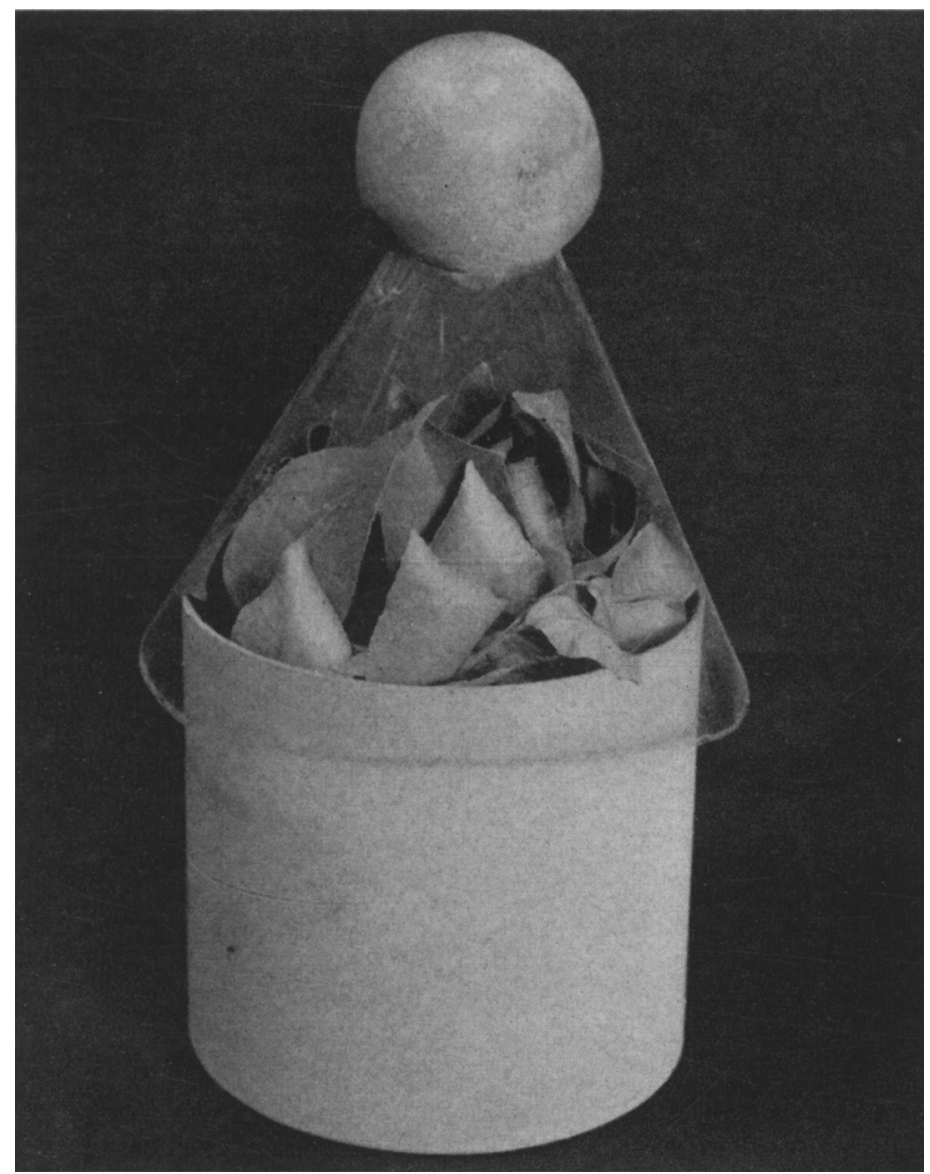

Fig. 3. Unit employed to collect eitrus red mites and their eggs. The mites crawl from the leaves to the grapefruit, where they congregate, feed, and oviposit.

and mite eggs were required daily for rearing predators, as well as for experimental purposes. These were obtained by a method developed by B. R. Bartlett of this station: A cylindrical cardboard container loosely filled with mite-infested citrus twigs was covered with a truncate celluloid cone open at both ends; a grapefruit was then placed on the small end of this cone (fig. 3). When such a unit is kept in a warm, lighted room, the mites crawl from the leaves to the grapefruit, where they congregate in large numbers, feed, and oviposit. 
Restriction of Prey to Preferred Areas. A preferred prey location on any one of the universes is that part, if any, which is most attractive to the greatest number of mites. On the universe of uniform light and topography (TypeI), the mites assumed a uniform distribution and there was no preferred area; consequently, when predator travel patterns were to be made using this type of universe, the mites were placed on the universe at a population density equivalent to one per square inch.

On the universe of varied light and uniform topography (Type-II), the preferred prey location was found to be the bright center of the lighted area; therefore, when the predators were being tested with the prey (mite eggs) under these conditions, the prey was restricted to a circular zone $13 / 8$ inches in diameter, centrally located in the illuminated area.

On the universe of uniform light and varied topography (Type-III), there was no preference between cone tips; consequently, when predator travel patterns were to be observed on this universe, 100 mites were placed at the tip of each cone. Although the mites were free to move about, it was found that the large majority remained within the top half inch of the cone.

On the universe of varied light and topography (Type-IV), the preferred location of the prey was at the tip of the cone in the illuminated area; the mites were therefore placed only at the tip of the lighted cone.

Restriction of Prey to Least-Preferred Areas. On the Type-I universe there was, as stated above, a uniform distribution of prey; hence, the conditions for a least-preferred area on this type of universe are the same as those described for a preferred area.

On a Type-II universe any one of the four corners of the floor of the universe proved to be equally unfavored; consequently, an area in the lower left-hand corner of the universe was arbitrarily selected as the least-preferred prey location under these conditions. This was a circular area $13 / 8$ inches in diameter, centered 3 inches from the border on a line bisectiong the $90^{\circ}$ angle of the corner of the floor of the universe. The prey, which consisted of mite eggs, was restricted to this area.

On Type-III and Type-IV universes the lower left-hand corner was again arbitrarily selected as the least-preferred spot, and the prey was restricted as described above.

\section{Procurement and Handling of Predators}

All the predators used in these experiments, except Conwentzia, were fieldcollected as eggs, and then reared in the laboratory with citrus red mites as food. Each species of predator was kept separate, and individuals of a given species were segregated in groups of similar ages, a procedure which served both to minimize cannibalism and to facilitate the selection of individuals of known ages for use in the various experiments.

Experiments were conducted to determine the ability of the larval stages of the predators to destroy large numbers of hosts, as well as their ability to develop to the adult stage on a minimum subsistence diet. The larvae were housed and fed individually in celluloid cells sealed on grapefruit with beeswax (fig. 4). The cell used was about 1/2-inch high and 1 inch in diameter, with a flat top depressed in the center to form a narrow convexly elevated 
area around the top edge. A small hole in the center of the top, through which the animals were placed in the cell, was kept plugged with cotton. This type of cell was selected because it facilitated the counting of large numbers of mites as they were placed in the cell, and because relatively few individuals escaped. Once inside the cell, the mites, owing to their negative geotropism,

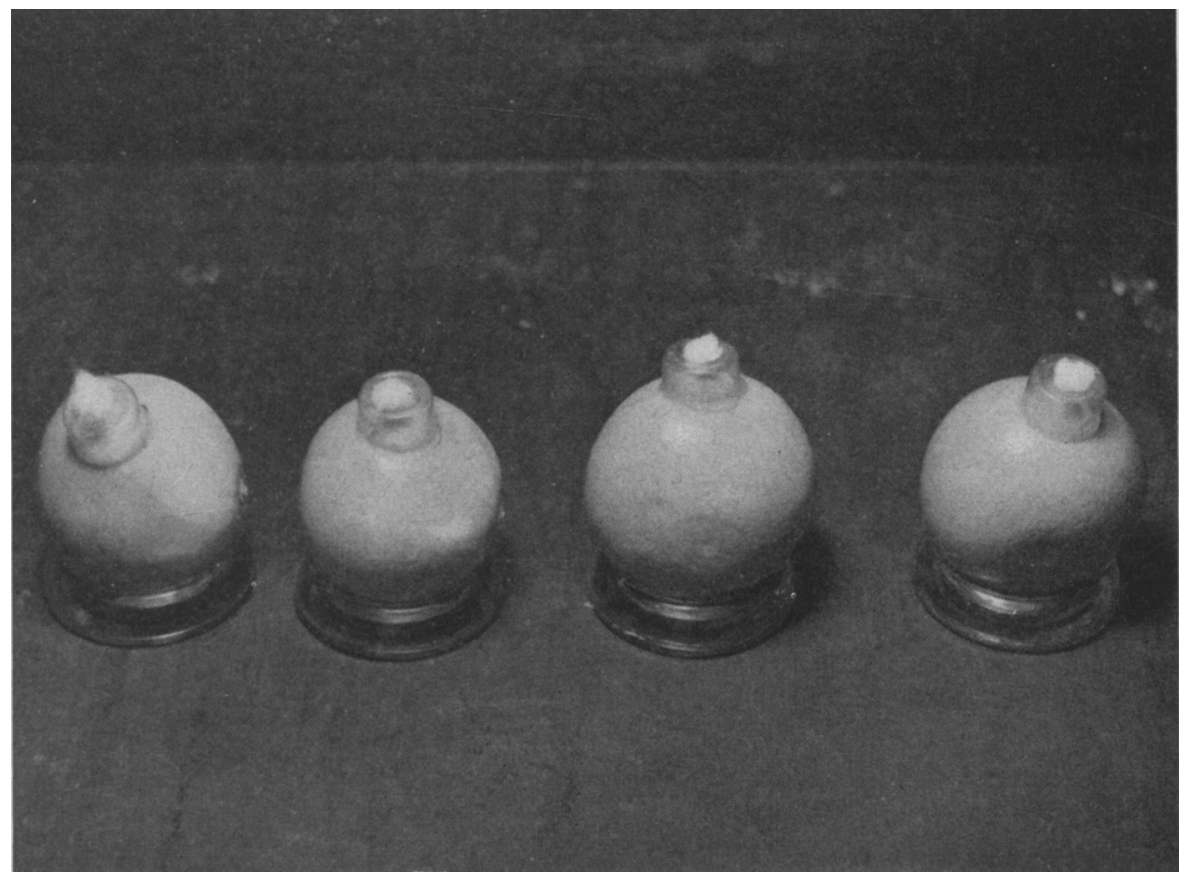

Fig. 4. Units employed to obtain feeding records of individual predator larvae. The celluloid cells were sealed on the grapefruit with beeswax. The hole in the top of each cell was plugged with cotton to prevent escape of the mites.

tended to congregate in the convex ridge of the cell top; thus few reached the opening. At the end of each 24 -hour period the cell was carefully removed and the predator was transferred to another cell containing mites. Counts were then made of the number of exoskeletons (only the body juices of the mites are consumed) and of the number of live mites in the removed cell. All predators and mites in these and in all other experiments were handled with a No. 0 sable-hair water-color brush.

To determine the average time required for the finding of hosts by a predatory species under various conditions, large numbers of predators were selected at random from stocks of early last-instar larvae starved for a period of about 4 hours and then released simultaneously in areas designated for the given type of universe being used. Individual predators were tested for rapidity of locomotion, and only those larvae were used which traveled at a speed approximating that judged to be average for the species. Last-instar larvae were used in all tests except the larval-feeding studies and tests on the newly hatched larvae because by far more searching and feeding are done in the last instar than in any of the others. 
Under conditions of varied light and uniform topography, the predators were released on the border of the illuminated area at the end of the universe farthest from the location selected as that least preferred by the prey. Under all other sets of conditions the predators were released in the center of the floor of the universe.

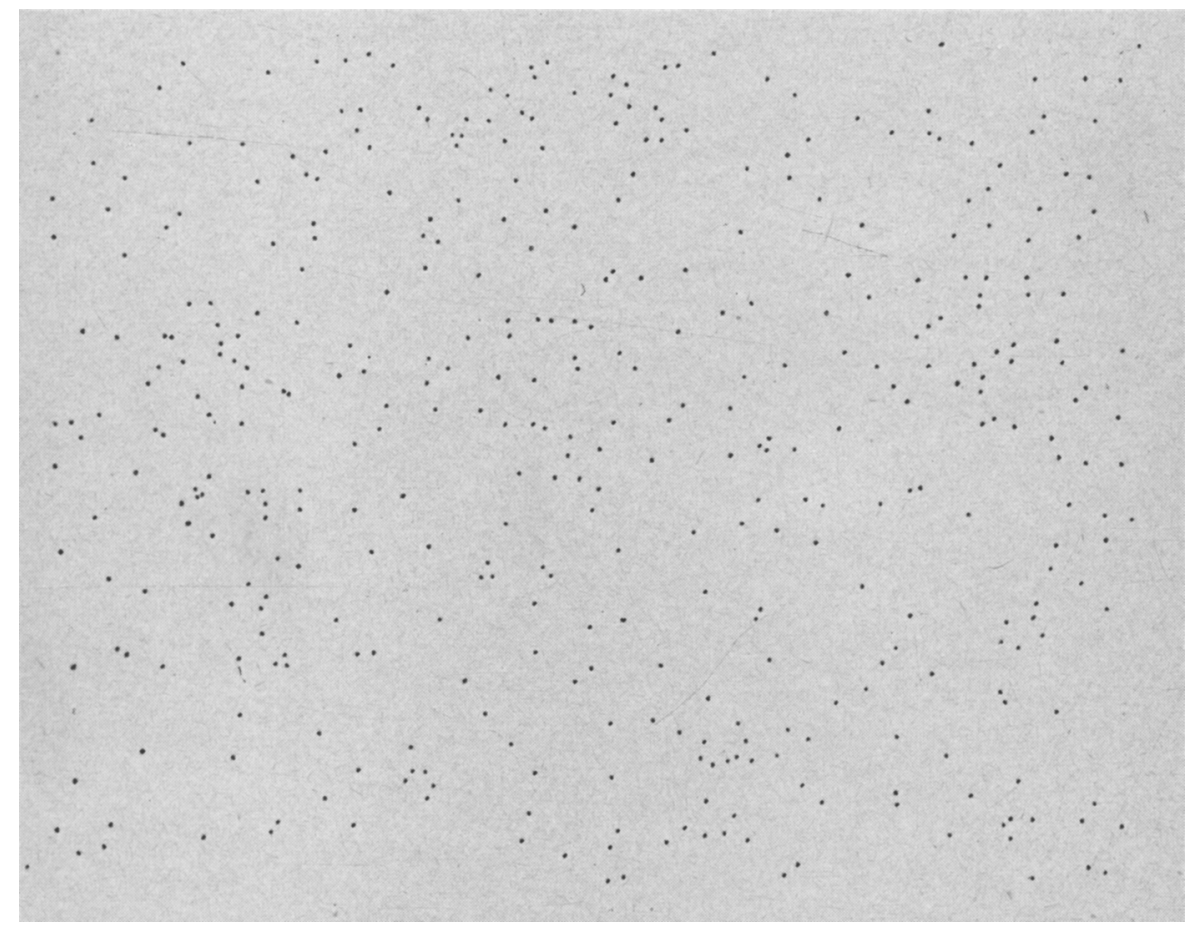

Fig. 5. Distribution of mite population on a Type-I universe (uniform light and topography).

\section{CORRELATED MOVEMENTS OF PREDATOR AND PREY STUDIED INDEPENDENTLY}

To gain an understanding of the means by which a given predaceous species discovers its prey, it is of fundamental importance to determine whether the movements of the predator in relation to areas likely to be inhabited by the prey are purely random; or whether there are, in the environment, factors which, to some degree, direct the predator to such an area. To determine these factors of association for a given predator and its prey, it is necessary to study their behavior independently under known conditions which can be accurately duplicated. The following results were obtained from a series of experiments devised to study the reactions of the experimental subjects in this respect.

Phototropic and Geotropic Responses of the Citrus Red Mite. When large numbers of the mites are released on a universe of uniform light and topography (Type-I), they disperse with random movement and become 
quite uniformly distributed over the face of the universe. The distribution pattern of 395 mites 4 hours after release on such a universe is shown in figure 5. When the universe is one in which light is varied on a uniform topography (Type-II), the population of mites migrates to the bright central portion of the illuminated area. Mite distribution 4 hours after release on this type of universe is shown in figure 6 . When the light is uniform but the topography is varied (Type-III universe), the population of mites be-

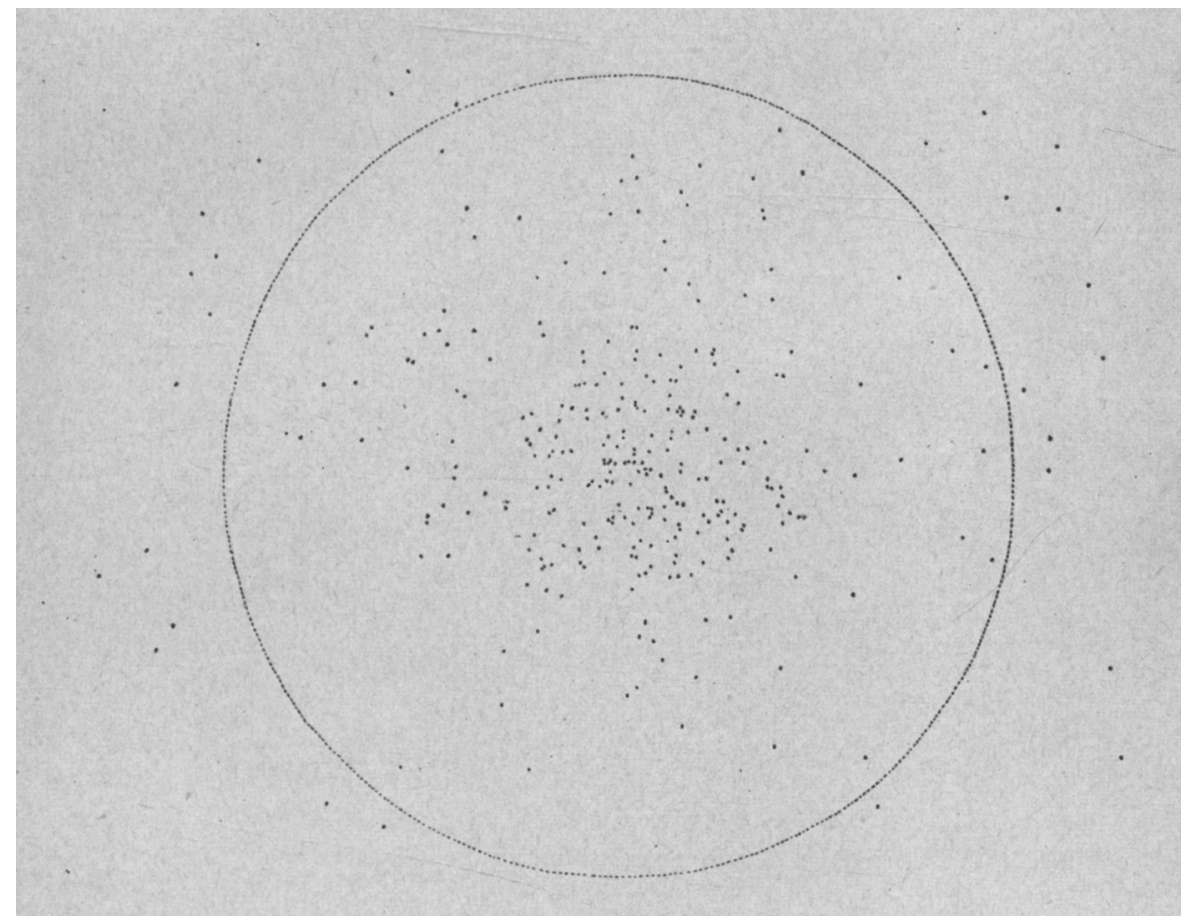

Fig. 6. Distribution of mite population on a Type-II universe (varied light and uniform topography). The dotted circle indicates the boundary of the illuminated area.

comes more or less equally divided and concentrated at the tips of the two cones (fig. 7) ; but when both light and topography are varied (Type-IV universe), practically the entire population of mites congregates at the tip of the illuminated cone (fig. 8).

The geotropic responses of all species of experimental subjects were tested in a photographic darkroom at room temperature and found to be essentially the same as those observed under the conditions of uniform light. Therefore, the geotropic responses depicted under these conditions represent fairly accurately the pattern which would be obtained in the absence of light. It should be noted, however, that with all species tested in these experiments, when phototropic stimuli were exerting influences in opposition to geotropic stimuli, the former had the greater influence on the experimental animal. For example, when the light source of the universe having varied topography 
was at the base of the cones, mites at the top were attracted to the light, and thus violated their purely geotropic responses.

These experiments demonstrate that the citrus red mite, Paratetranychus citri, is positively phototropic and negatively geotropic.

Phototropic and Geotropic Responses of the Predator Larvae. The reactions of the prey under certain environmental conditions having been determined, the predators also were subjected to these same conditions. The

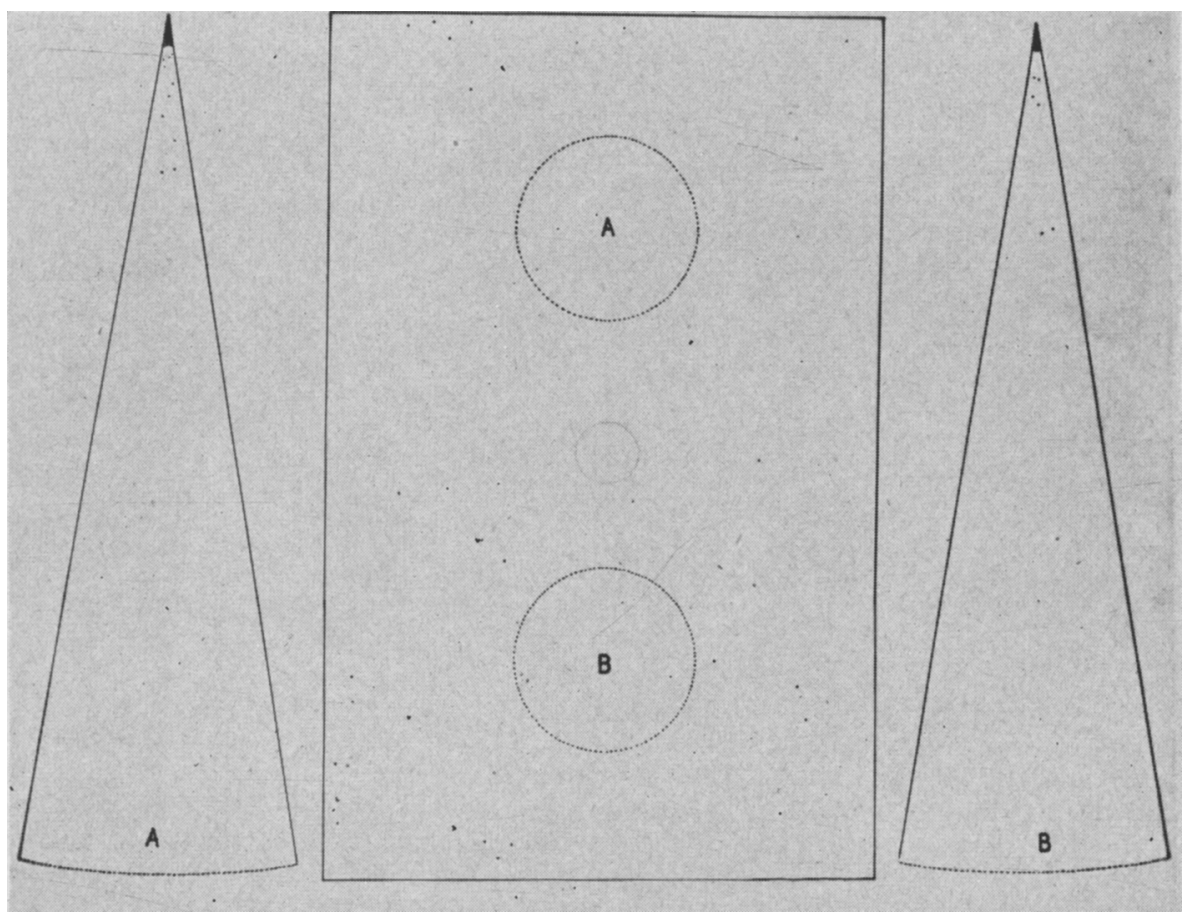

Fig. 7. Distribution of mite population on a Type-III universe (uniform light and varied topography). Note that the mite population is approximately equally divided and concentrated at the tips of the two cones.

searching patterns chosen to represent the reactions of the various species in these and in the following tests were selected after careful preliminary studies had been made under all of the experimental conditions.

When the predators were tested on a universe of uniform light and topography (Type-I), it was found that all three species searched with apparently random movements over the face of the universe. The searching patterns of larvae of Stethorus, Conwentzia, and Chrysopa during a 1-hour search on this type of universe are shown in figure 9, $a, b$, and $c$, respectively. Although all three species of predators searched in all major portions of the universe within the allotted time, the detailed patterns are distinctly different. Stethorus (fig. 9, a) makes numerous sharp curves, searching certain areas fairly well but leaving relatively large areas untraversed. Conwentzia (fig. 9, $b$ ) travels in a spiraling course, but, like Stethorus, makes frequent 
sharp turns, covers some areas rather thoroughly, and leaves relatively large areas unsearched. The searching pattern of Chrysopa (fig. 9, c) shows broadly rounded curves interrupted by relatively long stretches approaching a straight course, the area of the universe being quite uniformly searched within the hour.

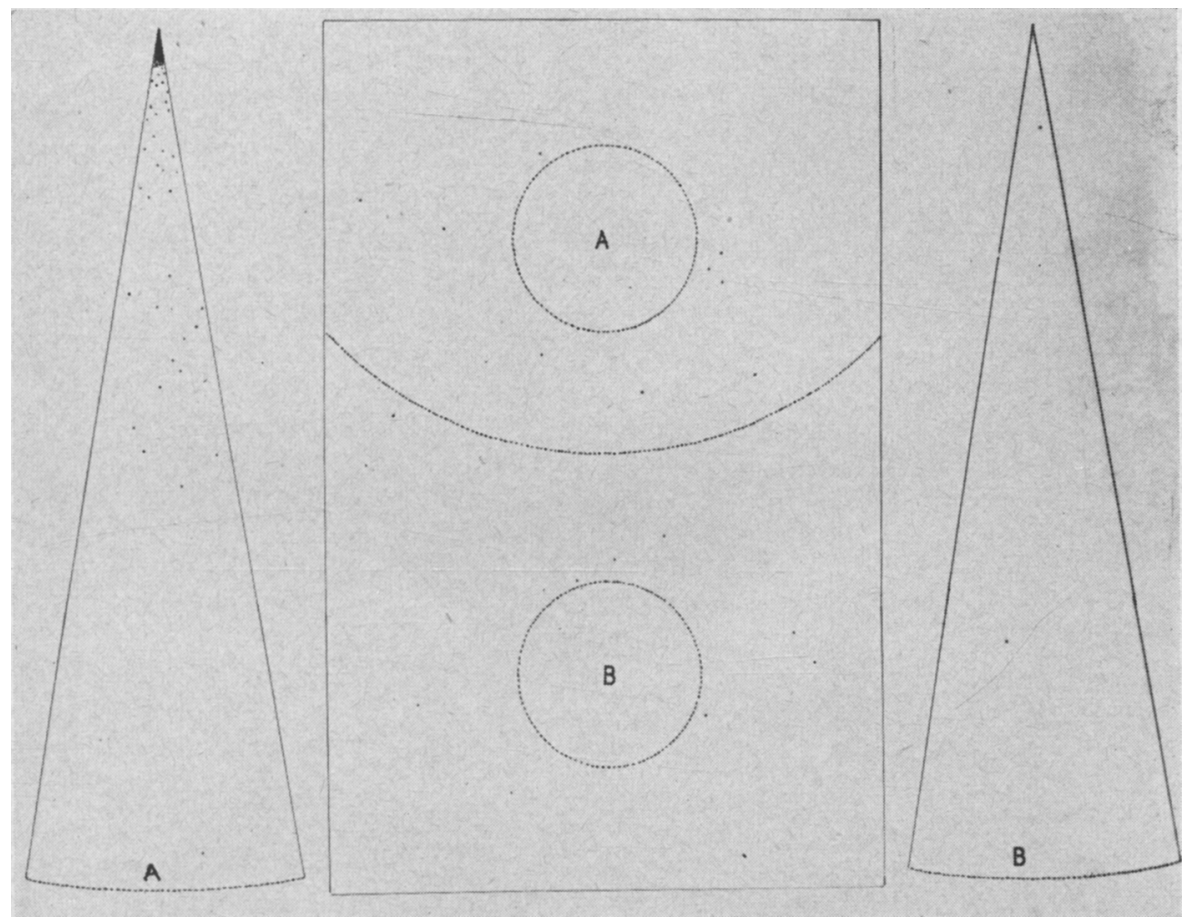

Fig. 8. Distribution of mite population on a Type-IV universe (varied. light and topography). The dotted are indicates the boundary of the illuminated area. $(A)$. Mite population largely concentrated at tip of illuminated cone $(A)$.

On a universe of varied light and uniform topography (Type-II), the reactions of the various species of predators are strikingly different. The area covered by a Stethorus larva during a 1-hour search (fig. 10, $a$ ) is restricted in general to the lighted area, the bright central portion being frequently traversed. The searching pattern of a Chrysopa larva under the same conditions (fig. 10,c) shows a definite preference for the dimly illuminated area at the boundaries of the circle; the bright center is traversed occasionally, however, and the dark area is also searched to some extent. The path of a Conwentzia larva under these conditions (fig. 10, $b$ ) is restricted to the dark portions of the universe; the lighted area is avoided.

Tests on a universe of uniform light and varied topography (Type-III) showed all species of predators under consideration to be negatively geotropic, but also revealed considerable variation in the degree of response of the different species to topographic influences. Figure 11, $a$ shows that negative geotropic response controls the actions of Stethorus to a marked degree, 
as most of its searching is restricted to the upper regions of one cone, which is ascended by random selection. In contrast, Chrysopa (fig. 11, c) searches more or less over the whole universe, with movement random in respect to choice of cones, but with a tendency to search the upper regions of both cones more thoroughly than any other portions. Figure 11, $b$ shows that
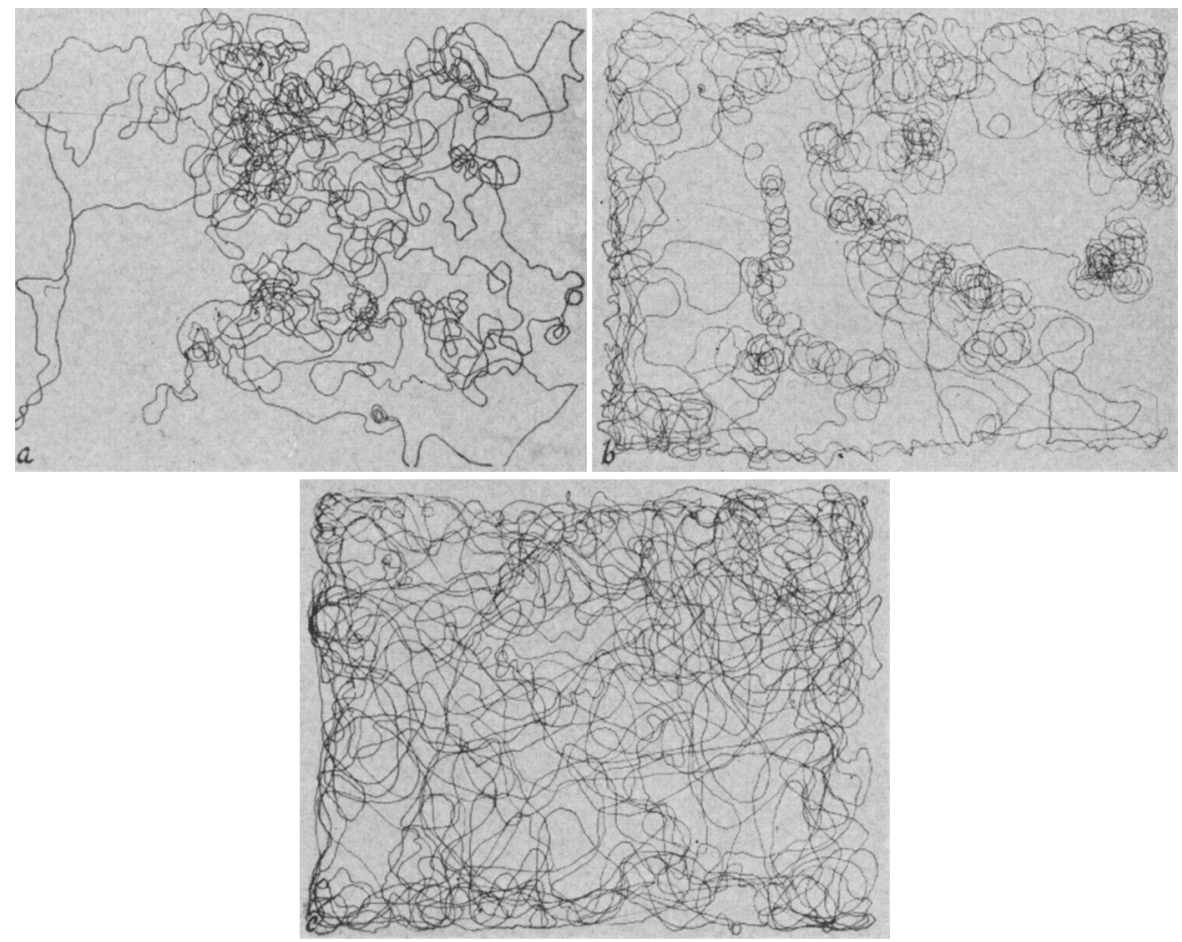

Fig. 9. Searching patterns made in a 1-hour period by a last-instar larva of each of the three predator species (a) Stethorus, (b) Conwentzia, and (c) Chrysopa on a Type-I universe (uniform light and topography). No prey (citrus red mites) present on universe.

Conwentzia, like Steithorus, generally restricts its searching to the upper regions of a single cone, but it descends the cone more readily than Stethorus and searches the floor of the universe fairly well.

Experiments conducted on a universe of varied light. and topography (Type-IV) yield results which would be expected in view of the knowledge thus far gained. Stethorus (fig. 12,a) ascends the lighted cone, and, owing to the attraction of the light immediately above the tip of the cone, plus a negative geotropic response, its movements are restricted to the vicinity of the top of the cone. This reaction is even more marked on this universe than on a Type-III universe (fig. 11, a). Chrysopa (fig. 12,c), under these conditions, favors the illuminated cone to the dark one, and the borderline area of light and dark to any other portion of the floor of the universe; however, the tips of both cones are more thoroughly searched than any other given areas on the universe. Conwentzia (fig. 12, $b$ ) searches in the dark area only, 
the tip of the dark cone being more thoroughly searched than any other portions of the dark area.

Summary of Results. In view of the fact that all of these experiments were conducted under controlled conditions with representatives of a single species of prey or predator on the universe during a given test, it must follow that the responses observed are due solely to the effect of the physical factors
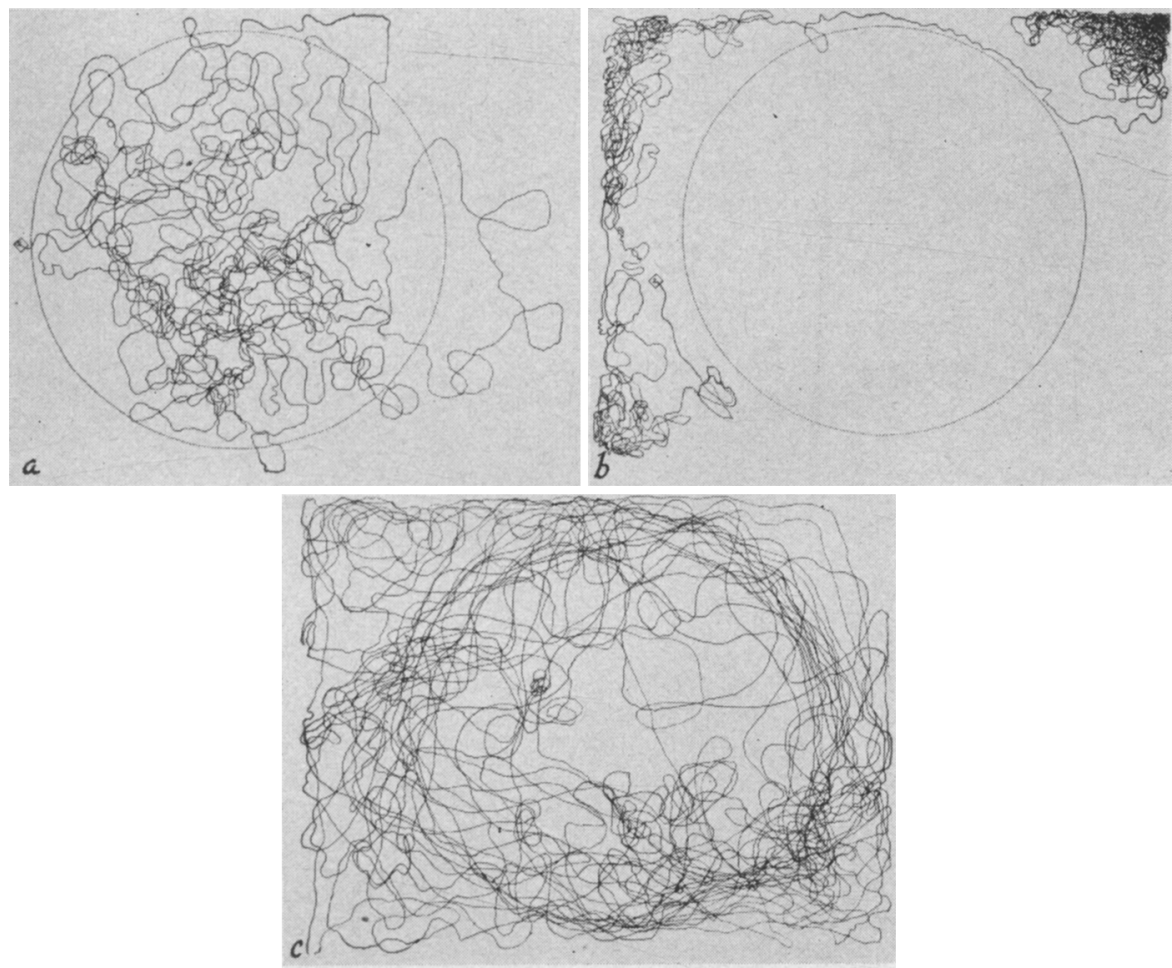

Fig. 10. Searching patterns made in a 1-hour period by a last-instar larva of each of the three predator species (a) Stethorus, (b) Conwentzia, and (c) Chrysopa on a Type-II universe (varied light and uniform topography). No prey (citrus red mites) present on universe.

concerned. Therefore, a consideration of the results obtained should reveal the degree of correlation, if any, between the movements of the prey and the predators.

When results are compared, it is found that the reactions of the predaceous species Stethorus picipes correspond very closely to those of the prey, Paratetranychus citri. The geotropic responses of Chrysopa californica are in general correlated with those of the prey, although the effect is not so pronounced as with Stethorus; the phototropic responses of Chrysopa are poorly correlated with those of the prey. The geotropic responses of Conwentzia hageni are closely correlated with those of the prey, but the phototropic responses are diametrically opposite. 
The foregoing experiments clearly demonstrate that, except in the phototropic responses of Conwentzia, the physical factors considered influence both predators and prey in somewhat the same manner to produce, under varied conditions, a correlated movement between predators and prey. It seems logical to assume that this correlated movement would render more probable the chance of a given predator to capture the prey. It is further

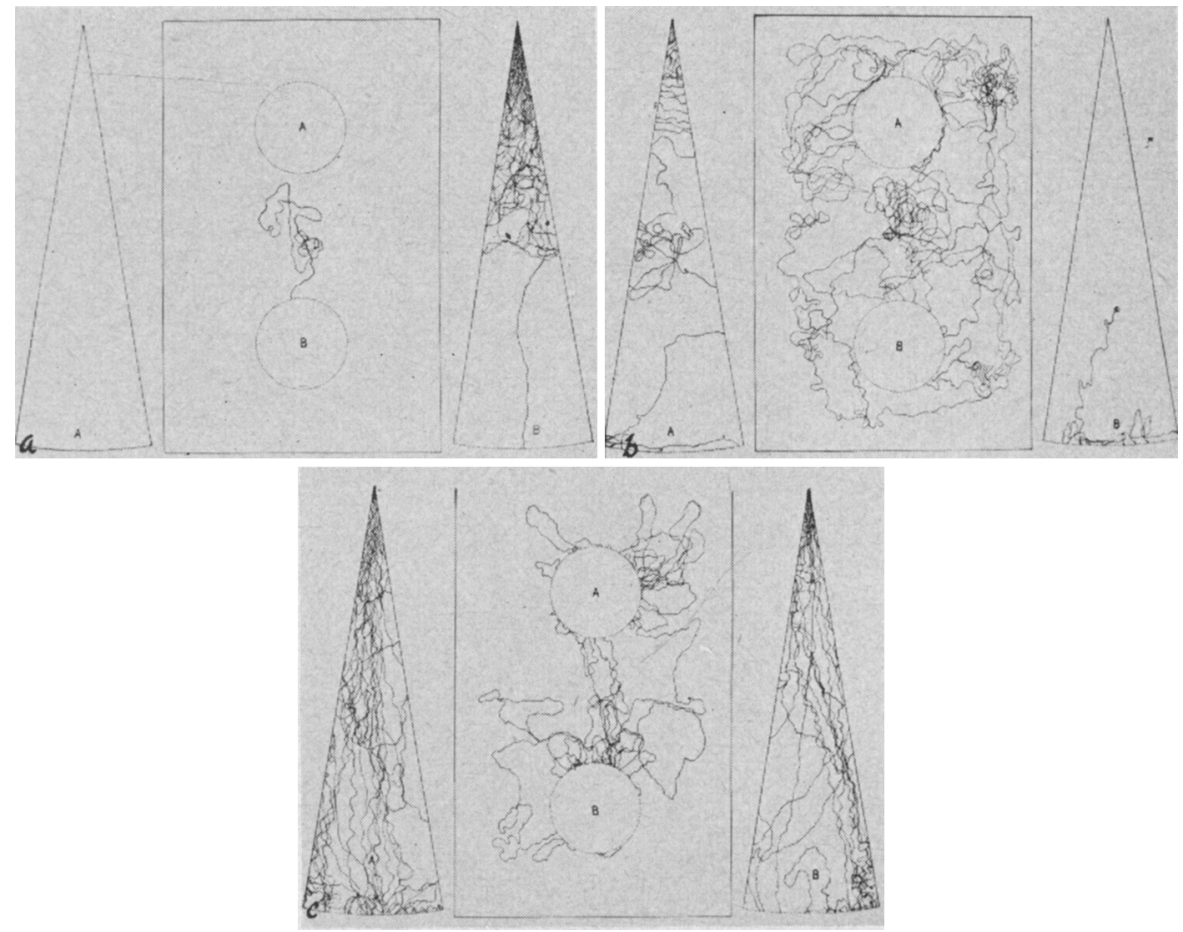

Fig. 11. Searching patterns made in a 1-hour period by a last-instar larva of each of the three predator species (a) Stethorus, (b) Conwentzia, and (c) Chrysopa on a Type-III universe (uniform light and varied topography). No prey (citrus red mites) present on universe.

shown that the degree of this correlated movement varies considerably with the different species. Numerous observations showed, however, that there is little variation in this respect between different individuals of the same species.

\section{REACTIONS OF PREDATOR SPECIES IN PRESENCE OF PREY Searching Ability}

Ability to Perceive Prey. The following experiments were set up to determine whether or not the presence of prey on the universe in any way affected the searching patterns of the predators-in other words, whether or not a given species of predator possesses some means of perceiving the location of the prey. In these experiments the same procedure was followed as in the 
preceding studies, except that here the prey was introduced onto the universe with the predator. In the first set of experiments the prey was confined to its least-preferred area.

The searching patterns of the predators were essentially the same in these experiments as in the preceding, except where the prey was discovered. It was therefore decided to time the movements of numbers of individuals of

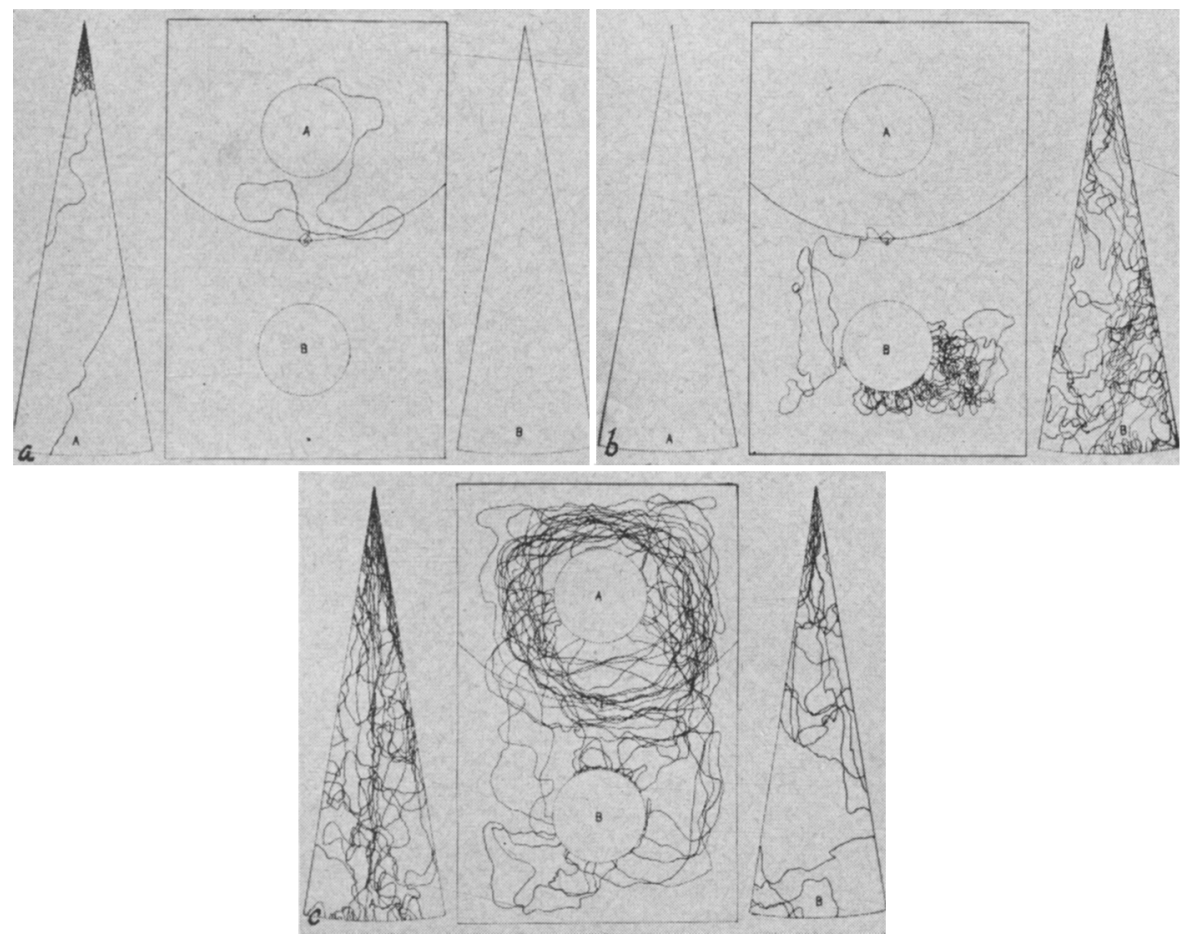

Fig. 12. Searching patterns made in a 1-hour period by a last-instar larva of each of the three predator species (a) Stethorus, (b) Coniwentzia, and (c) Chrysopa on a Type-IV universe (varied light and topography). No prey (citrus red mites) present on universe.

each species of predator to reach a given point of prey location on the universe. These time intervals were compared with those determined for numbers of individuals of each species of predator when no prey was present. Here again there was no significant difference between the reactions of subjects tested on universes void of prey and those on universes containing prey in strategic places. The timed movements of the predators searching the various types of universes, with prey in given locations, are shown in table 1. Since the timed movements of the predators tested on the universes when no prey was present were essentially the same, they are not reported here.

A study of table 1 shows that Stethorus readily discovers the prey when it is to be found in its preferred location, but seldom discovers it when it is in its least-preferred area. This information demonstrates that the directional movement of Stethorus, under these conditions, is determined by phototropic 


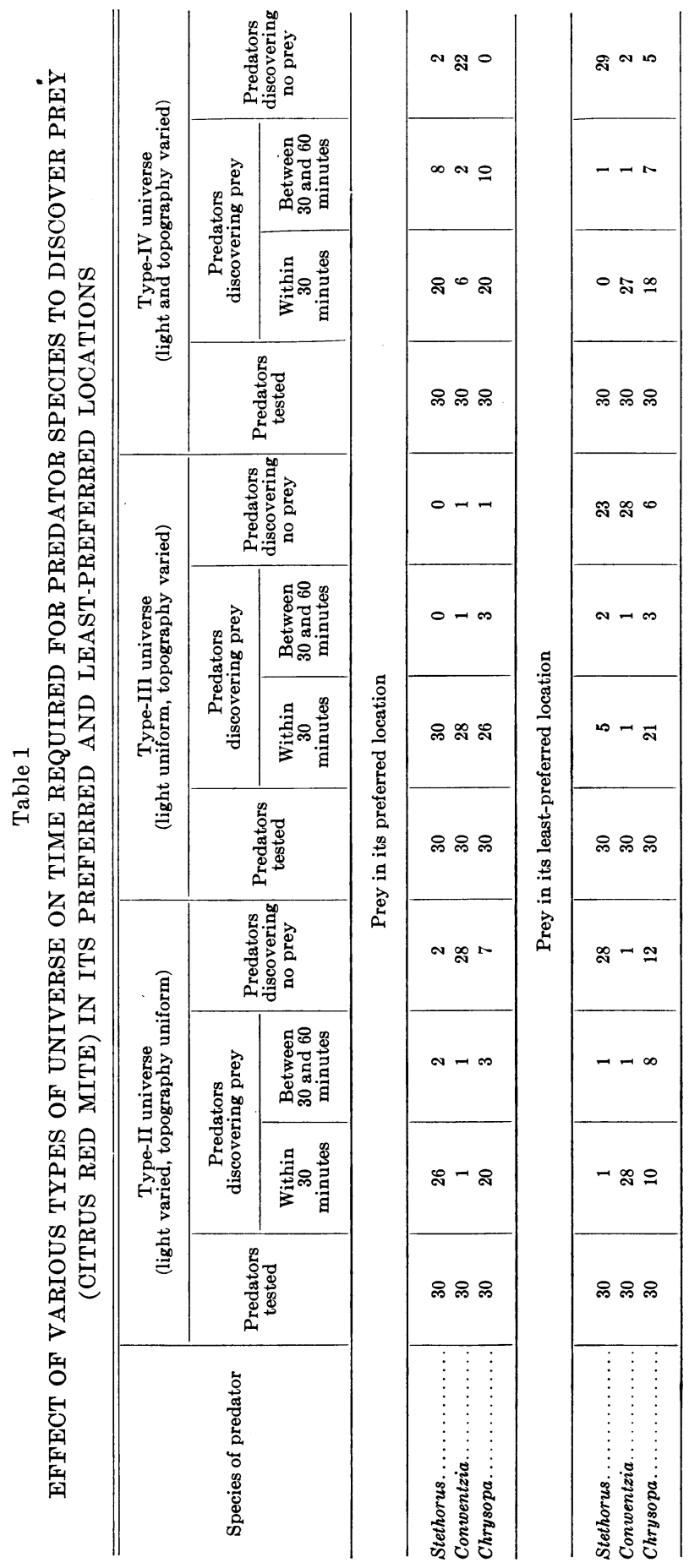


and geotropic responses, and is not affected by the presence of food in the environment.

Conwentzia discovers prey most readily when the prey is located in its least-preferred area, and seldom makes a discovery when the prey is in its preferred area. Thus it is seen that the directional movements of Conwentzia, also, are affected, not by the presence of prey in the environment, but by the physical factors, light and topography.

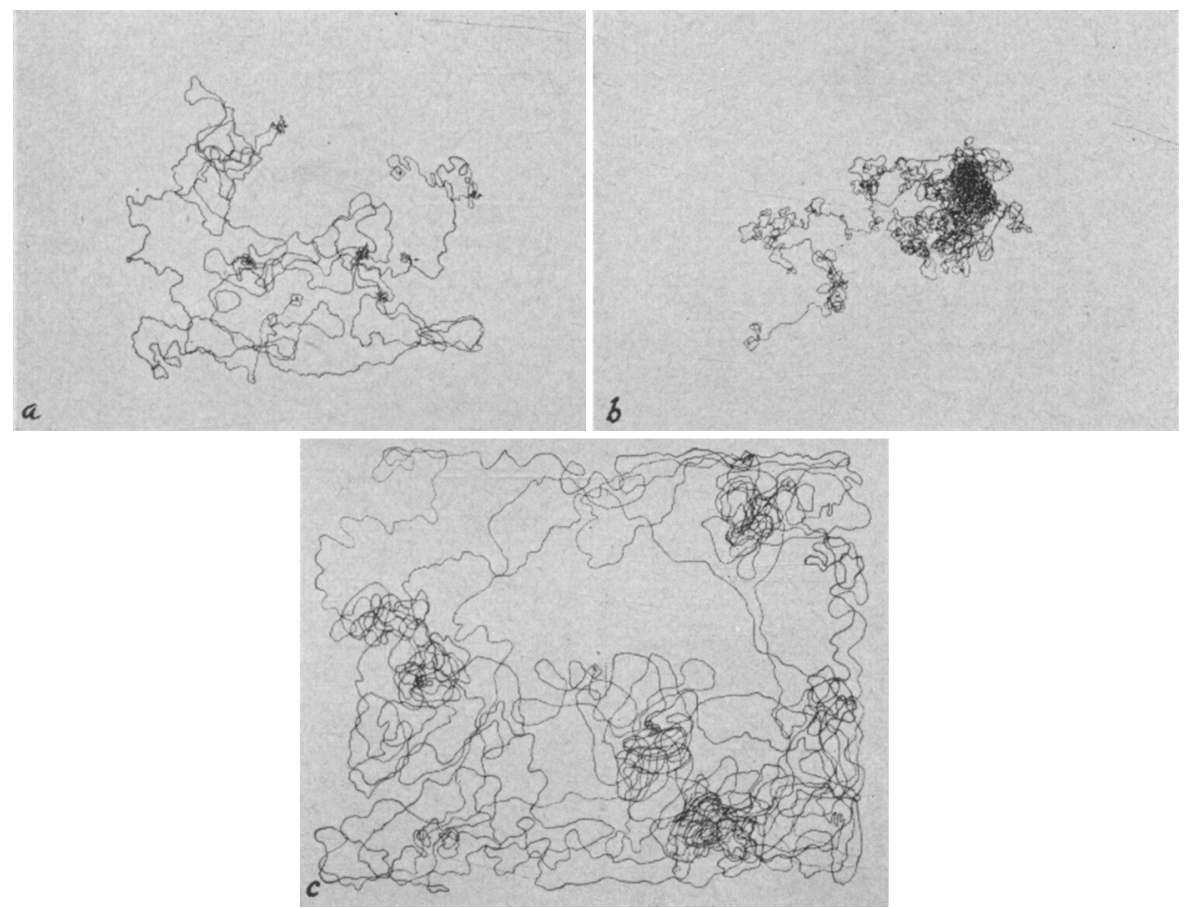

Fig. 13. Searching patterns made in a 1-hour period by a last-instar larvae of each of the three predator species ( $a$ ) Stethorus, (b) Conwentzia, and (c) Chrysopa on a Type-I universe (uniform light and topography). Prey present at a population density of one citrus red mite per square inch.

Chrysopa likewise demonstrated that its searching pattern is determined somewhat by phototropic and geotropic responses, and that it is not affected by the presence of prey in the various locations on the universes. In these experiments Chrysopa further demonstrated that, although its movements were not definitely directed to the area of the prey, under any of the various conditions of the universes it was fairly efficient in discovering the prey. This outstanding efficiency of Chrysopa in locating the prey is due to: a) its relative freedom from tropic limitations, as has been shown in figures 10 , 11 , and 12 ; and $b$ ) its greater speed and area of perception, as shown below.

The searching patterns of Stethorus, Conwentzia, and Chrysopa, when the prey is present on the Type-I universe at a population density of one mite per square inch, are shown in figure $13, a, b$, and $c$. When this figure is 
compared with figure $9, a, b$, and $c$, it may be seen that there is a distinct difference between the travel patterns when prey is being contacted at frequent intervals and when there is no prey present on the universe. When prey is being contacted, the paths are generally more tortuous, especially those of Stethorus and Conwentzia. After a mite has been consumed by these predators, the path leading away from the place of capture is twisted and circular, indicating a more thorough search of that particular area. There was no indication, however, that the predators were able to perceive the presence of the prey until contact was made. This type of behavior has been observed by Laing (1938) in work with Trichogramma and has been shown, under certain conditions, to increase the chance of Trichogramma's coming in contact with a neighboring egg.

The effect of this twisting movement on the searching pattern of the predators was especially noticeable when the heavy population density of the prey in restricted areas was encountered. Once larvae of Stethorus or Conwentzia contacted such a group of prey, they would usually feed an hour or longer without leaving the prey population, this occurring because their circling, twisting movement when prey is being frequently encountered enables them to make neighboring contacts readily. Chrysopa, as has been pointed out, changes its searching pattern when frequent contacts are being made, but it is not so efficient as Stethorus or Conwentzia in keeping within the area heavily populated with prey : its frequent long, quick dashes often take it beyond the location of the prey, which is not readily found again. Figure 14, $a$ shows the path of a Stethorus larva to the location of the prey on a universe of varied light and uniform topography (Type-II), where it remained feeding after contacting mites in the densely populated area. Figure 14, $b$ shows the path of a Chrysopa larva under the same conditions, leaving the prey area several times in the course of an hour.

These experiments, without exception, have indicated that none of the species of predators studied perceives the presence of prey on the experimental universe until an actual physical contact has been made.

In order to test further the powers of perception of the predators, numbers of individuals of each species were subjected to tests with a $\mathbf{Y}$-tube olfactometer. Here again there was no significant evidence to indicate that the presence of the host affected the movements of the predators.

Individuals of each species of predator were carefully observed with the aid of a binocular microscope to ascertain whether or not vision could be a factor in determining the area of perception of any of the experimental subjects. Again there were no indications that the prey was perceived at any distance. Although on occasions Stethorus larvae were observed apparently to give chase to a mite for a very short distance, careful observation with the microscope showed that there was, in every case, some actual physical contact between the predator and prey before such action was taken, and then if the mite were not contacted again within the distance of about 0.04 inches it was usually lost. Thus, sight is apparently not a factor in this momentary burst of speed, which is evidently only a response to contact with the prey. 


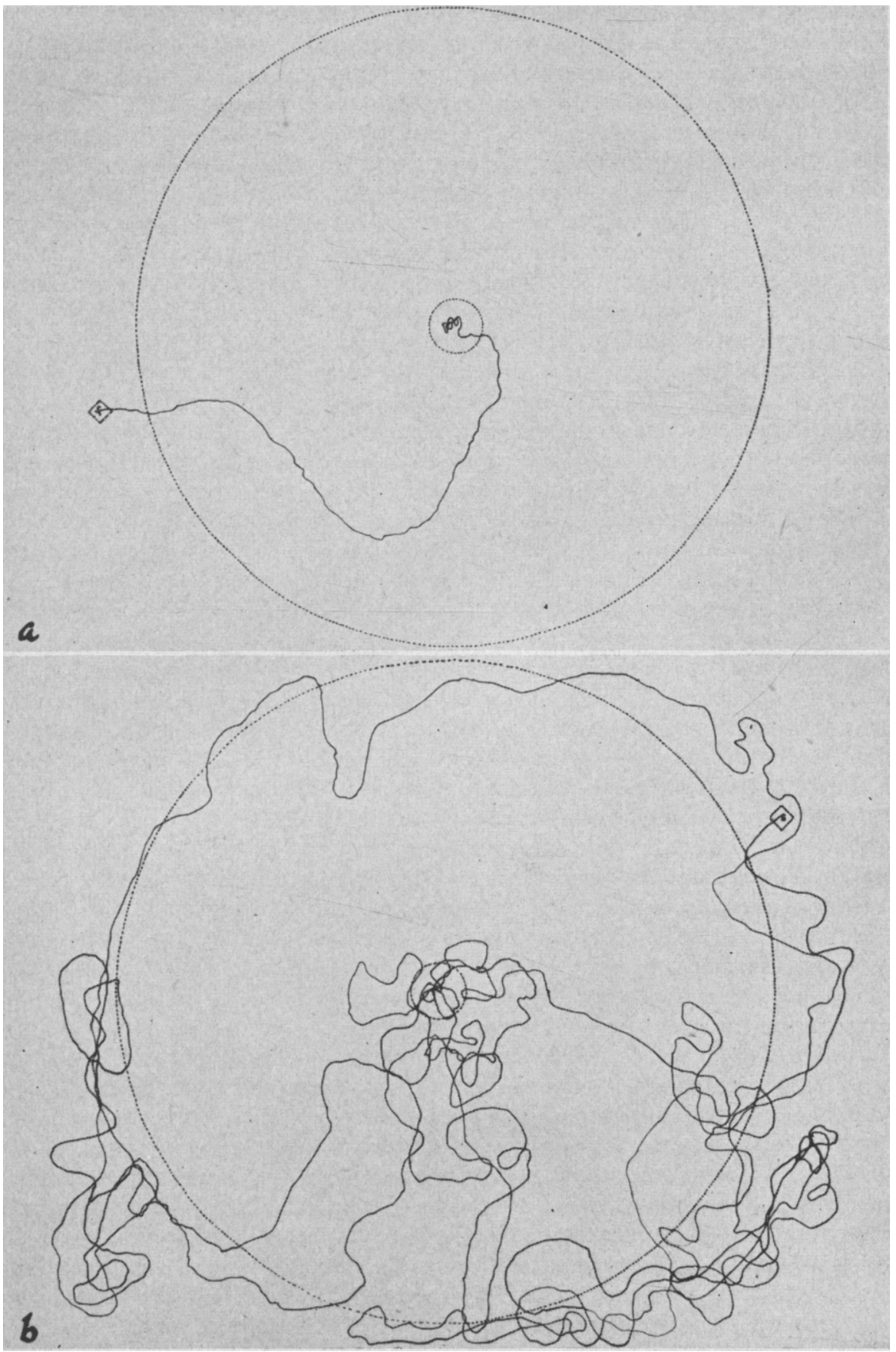

Fig. 14. Paths made in a 1-hour period by a last-instar larva of each of the predator species (a) Stethorus and (b) Chrysopa on a Type-II universe (varied light and uniform topography), with prey (citrus red mites) present in restricted area in preferred location. 
For each predaceous species tested, the area of perception was found to be limited to tactile responses of some type. The area of perception of Stethorus appears to be the distance from the tip of the longest laterally extending bristle of the head capsule on one side, to the tip of the longest laterally extending bristle on the opposite side. This distance, measured with a micrometer and binocular microscope on 25 larvae, averaged 0.02 inches.

The area of perception of Chrysopa, as nearly as could be ascertained, is the distance between the tips of the mandibles, which are carried widely separated as the larva travels in search of prey. This distance, from measurements made on 25 individuals, was found to average 0.04 inches. Occasionally, a Chrysopa larva will reach around with its mandibles and grasp a mite which has contacted some portion of one of its legs, or will even bend its head backwards over its body to seize a mite located on the dorsum of its abdomen. Although these reactions may be a factor in the area of perception of the Chrysopa larvae, they occur so infrequently that it would be difficult to evaluate their importance accurately; consequently, their effect on the area of perception is not taken into consideration in these studies.

The area of perception of Conwentzia was determined to be the distance from the tip of one palpus to the tip of the other. The palpi are broad and fleshy and extend out on either side of the head. The average distance from tip to tip, determined from the measurements of 20 larvae, is 0.02 inches.

The foregoing experiments demonstrate rather conclusively that the predators are unable to perceive the prey before contact is made; they also indicate that in a Type-I universe (uniform light and topography) the search for prey is entirely random. That the searching is random is proved more conclusively in an experiment described later.

Area Effectively Searched. To determine the area effectively searched by a predator in a given period, it is necessary to know the area of perception, speed of searching, total area searched, and the ratio of the number of prey captures to the number of times the prey is contacted.

As shown above, the area of perception for Stethorus is 0.02 inches; for Chrysopa, 0.04 inches; and for Conwentzia, 0.02 inches.

A value used to represent the speed in searching for each species of predator was determined by taking an average of the distance traveled within 1 hour by 10 different individuals. The distance traveled was measured by closely following the larva with a cartographer's wheel. As shown in table 2, the average speed of Stethorus was 774 inches per hour; that of Conwentzia, 1,300 inches per hour; and that of Chrysopa, 2,675 inches per hour.

The total area searched reveals to some extent the efficiency of a given predator ; it is by no means an exact measure, as it does not necessarily correspond to the area effectively searched. To quote Nicholson (1933, p. 144) : "The area effectively traversed by an average individual during its lifetime will be referred to as the area of discovery of the species under the given conditions. For example, if an average individual fails to capture, say, half the objects of the required kind that it meets, then the area of discovery is half the area traversed."

When the total area searched in a given period was calculated by multiplying the area of perception by the speed of travel, it was found, as shown 
in table 3, that Stethorus searched a total area of 15.48 square inches per hour; Conwentzia, 26 square inches per hour; and Chrysopa, 107 square inches per hour.

To determine the ratio of captures to contacts, the prey was placed on a Type-I (uniform) universe at a density of one individual for each square inch. Since the mites were alive and free to move about, this exact distribu-

Table 2

SEARCHING SPEED (FEET PER HOUR) OF PREDATOR SPECIES*

\begin{tabular}{|c|c|c|c|}
\hline Test number & Stethorus & Conwentzia & Chrysopa \\
\hline $1 \ldots \ldots \ldots \ldots \ldots \ldots \ldots \ldots \ldots \ldots \ldots$ & 50 & 83 & 187 \\
\hline $2 \ldots \ldots \ldots \ldots$ & 54 & 91 & 192 \\
\hline $3 \ldots \ldots \ldots$ & 57 & 93 & 198 \\
\hline $4 \ldots \ldots \ldots$ & 65 & 102 & 204 \\
\hline $5 \ldots$ & 66 & 111 & 209 \\
\hline $6 \ldots$ & 68 & 117 & 222 \\
\hline $7 \ldots \ldots \ldots$ & 69 & 117 & 231 \\
\hline $8 \ldots \ldots \ldots \ldots \ldots \ldots \ldots \ldots \ldots \ldots$ & 71 & 121 & 251 \\
\hline $9 \ldots \ldots \ldots \ldots \ldots \ldots \ldots \ldots \ldots$ & 72 & 123 & 264 \\
\hline $10 \ldots \ldots \ldots \ldots \ldots \ldots \ldots \ldots \ldots \ldots \ldots \ldots$ & 73 & 125 & 271 \\
\hline \multirow{3}{*}{$\begin{array}{l}\text { Average: } \\
\text { Feet per hour. } \ldots \ldots \ldots \ldots \ldots \ldots \ldots \\
\text { Inches per hour. } \ldots \ldots \ldots \ldots \ldots \ldots\end{array}$} & & & \\
\hline & 64.5 & 108.3 & 222.9 \\
\hline & 774 & 1,300 & 2,675 \\
\hline
\end{tabular}

* Average for 10 individuals of each species.

Table 3

AREA EFFECTIVELY SEARCHED BY LARVAE OF EACH SPECIES OF PREDATOR IN A PERIOD OF ONE HOUR (PREY POPULATION DENSITY, ONE MITE PER SQUARE INCH)

\begin{tabular}{|c|c|c|c|c|c|c|c|}
\hline Species of predator & $\begin{array}{c}\text { Area of } \\
\text { perception, } \\
\text { in inches }\end{array}$ & $\begin{array}{l}\text { Searching } \\
\text { speed, } \\
\text { in inches } \\
\text { per hour }\end{array}$ & $\begin{array}{l}\text { Total area } \\
\text { searched, } \\
\text { in square } \\
\text { inches }\end{array}$ & $\begin{array}{c}\text { Total } \\
\text { number of } \\
\text { contacts } \\
\text { with prey }\end{array}$ & $\begin{array}{c}\text { Total } \\
\text { number of } \\
\text { captures }\end{array}$ & $\begin{array}{c}\text { Ratio, } \\
\text { captures to } \\
\text { contacts }\end{array}$ & $\begin{array}{c}\text { Area } \\
\text { effectively } \\
\text { searched, } \\
\text { in square } \\
\text { inches* }\end{array}$ \\
\hline Stethorus. & 0.02 & 774 & 15.48 & 29 & 10 & $1: 2.9$ & 5.34 \\
\hline Conwentzia. & 0.02 & 1,300 & 26.00 & 50 & 11 & $1: 4.5$ & 5.78 \\
\hline Chrysopa.. & 0.04 & 2,675 & 107.00 & 149 & 149 & $1: 1$ & 107.00 \\
\hline
\end{tabular}

* Total area searched $\times$ ratio of captures to contacts.

tion was, of course, not maintained. However, as shown in figure 5, the movement of the prey under these conditions is random, and a fairly uniform distribution results. Ten individuals of each species of predator were tested, one at a time, for a period of one hour under these conditions. A stop watch was used to time the number of contacts and captures made within the hour. When a capture was made, the watch was stopped until the captured prey was discarded and the search resumed. By this method a full hour of searching time was allowed for each predator tested. Reference to table 3 shows that Stethorus averaged 29 contacts and 10 captures per hour; Conwentzia, 50 contacts and 11 captures per hour; and Chrysopa, 149 contacts and 149 captures per hour. 
The marked variation exhibited in the ability of these species of predators to capture the prey after a contact has been made, is largely due to anatomical differences of the species. The mouth parts of larvae of Conwentzia, for example, consist of a cone-shaped beak enclosing needlelike mandibles and maxillae, poorly suited for grasping motile prey. The mouth parts of the larvae of Stethorus, on the other hand, are in lateral opposition and work with a pincerslike movement; thus, even though they extend but slightly beyond the margin of the head capsule, they are more efficient in grasping the prey than those of Conwentzia. The high degree of efficiency exhibited by Chrysopa larvae in capturing the prey is possible because of the maneuverability and size of the long, curved, lancelike mandibles extended well beyond the head margin, plus the added advantage of a comparatively long, flexible cervical region which permits the free movement of the entire head capsule in all directions. These advantages are further enhanced by well-developed muscle coordination. All the predators tested in these experiments also feed on eggs of the citrus red mite, however, and all have mouth parts well suited for this purpose.

When the total area searched by each species in a 1-hour period is multiplied by the ratio of captures to contacts, the area effectively searched in this period is determined. As shown in table 3, this area for Stethorus was 5.34 square inches; for Conwentzia, 5.78 square inches; and for Chrysopa, 107 square inches.

Ability to Search in Crevices and Through Protective Coverings. The citrus red mite is smaller than any of the predators considered in this study, and although this mite is generally found in locations readily accessible to the predators it seemed desirable to know which of them could search out the mite in the smallest crevices. This information was obtained by carefully adjusting the space between a microscope slide and a square cover glass until the minimum spacing had been reached at which the experimental subjects could search effectively for the prey. By this method it was found that Stethorus can search in spaces as small as $0.22 \mathrm{~mm}$, Conwentzia in spaces as small as $0.39 \mathrm{~mm}$, and Chrysopa in spaces as small as $0.67 \mathrm{~mm}$. Although Chrysopa cannot search in so small a crevice as the other two species, it can probe the length of its long, thin mandibles into spaces inaccessible to Stethorus and Conwentzia. Furthermore, Chrysopa has a tendency to probe into small holes and cracks, even at times forcing its body into narrow places, a tendency not demonstrated by the other two species.

The ability of the predators to search through protective coverings is perhaps of little importance in their ability to search for the prey, as the mites are seldom to be found in such protected areas. This capacity assumes importance, however, when it is recalled that these species of predators prey on each other, and when it is further pointed out that Conwentzia and Chrysopa are protected in their pupal stages by silken cocoons. Numerous other species of insects which might serve as additional food for the predators when the prey population is at a low density are also to be found under protective coverings. Therefore, it was desirable to have some measure of the ability of the experimental subjects to search through protective coverings, of which there are, of course, many types and textures in nature. 
The object of this experiment was merely to determine the general reactions of the predators when confronted with a situation such as that described. above. These reactions were determined by placing a number of mites in a single-depression microscope culture slide, covering the depression with a small piece of bleached muslin and then inverting a similar slide, containing a single predator larvae in its depression, over the first slide in such a manner that the hollows of the slides directly opposed each other, with the muslin serving as a diaphragm separating the prey and predator.

Several repetitions of this simple experiment with each species of predator demonstrated that the Chrysopa larvae readily pierce the cloth with their long, sharp mandibles and feel about for prey. When the prey is contacted, it is quickly grasped between the two mandibles, the body juices are sucked out, and the crumpled skin is cast aside. Even when the prey was removed from the bottom slide, the Chrysopa larvae continued to probe through the cloth in an attempt to find food. Neither of the other two species of predators made any attempt to penetrate the cloth with their mouth parts. These observations indicate that Chrysopa would be more efficient than Conwentzia or Stethorus in searching through protective coverings.

\section{Feeding Ability}

Maximum Feeding Tests. The ability of a predator to destroy large numbers of its prey assumes importance in a situation where there is a high population density of the prey. To determine the ability of the various species of predators in this respect, daily records were kept, throughout the larval period, of the number of mites destroyed by individuals of each species when confined in a small area with a surplus number of prey. (See page 237 for explanation of procedure.)

Results of these experiments (table 4) show that the maximum number of mites destroyed by a single Stethorus larva in the fourth instar was 190, and during the entire larval period, 486. The maximum number of mites destroyed by a single Chrysopa larva during the third instar was 9,580, and during the entire larval period, 11,211.

Repeated trials to rear Conwentzia from egg to adult in the laboratory failed. Therefore, larvae were collected in the field and fed on mites in the laboratory until ready for the fourth instar, and results are reported for this instar only (table 4). The maximum number of mites destroyed in this instar by an individual Conwentzia larva was 319 .

Ability to Consume Prey Quickly. In a moderately heavy infestation, where a certain amount of time must be spent by the predator in searching for the prey, the speed with which the prey is consumed may be a factor in determining whether or not a given predator can consume its maximum number of prey. The speed of prey consumption may also be a factor determining the ability of a predator to obtain its daily food requirements at a very low prey population density.

The average time required by each predator to consume one female mite is shown in table 5. These averages were computed from records obtained by carefully timing five separate feedings (one mite per feeding) of four individuals of each species of predator. As the table shows, the average feeding 
time for Chrysopa is 8.6 seconds, and for Conwentzia it is 84.4 seconds. Both of these predators suck out the body juices of the mites in a single, continuous action. The prolonged feeding of Stethorus, whose average time is 357.5 seconds per mite, is largely due to the peculiar method used by this predator, the contents being alternately pumped out of, and forced back into, the body

Table 4

RECORDS OF MAXIMUM FEEDING TESTS OF LARVAE OF THE THREE PREDATOR SPECIES

\begin{tabular}{|c|c|c|c|c|c|c|c|c|c|c|c|}
\hline \multirow{2}{*}{$\underset{\text { number }}{\text { Larva }}$} & \multicolumn{2}{|c|}{ First instar } & \multicolumn{2}{|c|}{ Second instar } & \multicolumn{2}{|c|}{ Third instar } & \multicolumn{2}{|c|}{ Fourth instar } & \multirow{2}{*}{$\begin{array}{c}\text { Daily } \\
\text { average } \\
\text { of mites } \\
\text { eaten in } \\
\text { last instar }\end{array}$} & \multirow{2}{*}{$\begin{array}{l}\text { Total } \\
\text { days in } \\
\text { larval } \\
\text { period }\end{array}$} & \multirow{2}{*}{$\begin{array}{l}\text { Total } \\
\text { number } \\
\text { of mites } \\
\text { eaten }\end{array}$} \\
\hline & Days & $\begin{array}{l}\text { Number } \\
\text { of mites } \\
\text { eaten }\end{array}$ & Days & $\begin{array}{c}\text { Number } \\
\text { of mites } \\
\text { eaten }\end{array}$ & Days & $\begin{array}{l}\text { Number } \\
\text { of mites } \\
\text { eaten }\end{array}$ & Days & $\begin{array}{c}\text { Number } \\
\text { of mites } \\
\text { eaten }\end{array}$ & & & \\
\hline
\end{tabular}

Stethorus

\begin{tabular}{r|r|r|r|r|r|r|r|r|r|r|r|r}
\hline$\ldots \ldots \ldots$ & 4 & 73 & 2 & 146 & 2 & 173 & 2 & 94 & 47 & 10 & 486 \\
$2 \ldots \ldots \ldots$ & 2 & 26 & 2 & 85 & 2 & 163 & 2 & 122 & 61 & 8 & 396 \\
$3 \ldots \ldots \ldots$ & 3 & 54 & 1 & 55 & 1 & 119 & 2 & 190 & 95 & 7 \\
$4 \ldots \ldots \ldots$ & 2 & 30 & 1 & 38 & 2 & 144 & 2 & 169 & 84.5 & 7 \\
$5 \ldots \ldots \ldots$ & 2 & 34 & 1 & 39 & 1 & 66 & 2 & 108 & 54 & 6 & 381 \\
\hline
\end{tabular}

Chrysopa

\begin{tabular}{r|r|r|r|r|r|r|r|r|r|r|r}
\hline $1^{*} \ldots \ldots \ldots$ & 5 & 370 & 6 & 1,261 & 8 & 9,580 & $\ldots$ & $\ldots$ & $1,197.5$ & 19 & 11,211 \\
$2 * \ldots \ldots$ & 4 & 270 & 6 & 1,044 & 7 & 6,449 & $\ldots$ & $\ldots$ & 921.2 & 17 & 7,763 \\
$3 \ldots \ldots \ldots$ & 3 & $\mathbf{4 7 4}$ & 2 & 491 & 6 & 9,088 & $\ldots$ & $\ldots$ & $1,514.6$ & 11 & 10,053 \\
$4 \ldots \ldots \ldots$ & 3 & 397 & 3 & 704 & 6 & 8,723 & $\ldots$ & $\ldots$ & $1,453.8$ & 12 & 9,824 \\
$5 \ldots \ldots \ldots$ & 4 & 489 & 3 & 768 & 6 & 9,413 & $\ldots$ & $\ldots$ & $1,568.7$ & 13 & 10,670 \\
\hline
\end{tabular}

Conwentzia $\dagger$

\begin{tabular}{|c|c|c|c|c|c|c|c|c|c|c|c|}
\hline $1 \ldots \ldots \ldots$ & . & $\ldots$ & $\ldots$ & $\ldots \ldots$ & .. & $\ldots$ & 3 & 95 & 31.6 & .. & $\ldots \ldots$ \\
\hline $2 \ldots \ldots \ldots$ & . & $\ldots$ & . . & $\ldots \ldots$ & . . & $\ldots$ & 6 & 319 & 53.1 & .. & $\ldots \ldots$ \\
\hline 3. & .. & $\ldots$ & $\ldots$ & $\ldots$ & $\ldots$ & $\ldots \ldots$ & 4 & 172 & 43 & .. & $\ldots \ldots$ \\
\hline 4. & .. & $\ldots$ & $\ldots$ & $\ldots \ldots$ & $\ldots$ & & 3 & 118 & 39.3 & .. & $\ldots \ldots$ \\
\hline $\mathbf{5} \ldots \ldots \ldots$ & .. & $\ldots$ & $\ldots$ & $\ldots$ & $\ldots$ & $\ldots \ldots$ & 6 & 282 & 47 & .. & $\ldots \ldots$ \\
\hline
\end{tabular}

* Larva inadvertently not fed a sufficient number of mites for maximum feeding requirements in first two instars.

$\dagger$ Repeated trials to rear Conwentzia from egg to adult in the laboratory failed; therefore, larvae collected in the field and fed on mites until they reached the fourth instar were used for this experiment. Although these larvae lived for several days after feeding had ceased, none pupated.

of the mite. This procedure is usually repeated six or eight times before the body is finally pumped dry and the shriveled skin is cast aside.

Minimum Feeding Tests. To determine the minimum quantity of food (number of mites) required daily by the predators to complete their larval development, individual larvae were fed a given fraction of the maximum number of mites consumed by a "typical" individual of its species. This fraction was decreased until the minimum daily requirements were determined.

It was found that the number of days spent in each instar increased as the quantity of food was decreased. Therefore, the number of mites fed to the predators daily, for the days spent in any one instar in the minimum feeding tests beyond the total number of days spent in that instar in the 
maximum feeding tests, was the given fraction of the number of mites eaten in the last full day's feeding of that instar in the maximum feeding tests. For example, the Stethorus larva of the maximum feeding tests (no. 1, table 4) used as a guide for the minimum feeding tests spent 2 days in the fourth instar, eating 91 mites the first day and 3 mites the second day ; but the larvae in the minimum feeding tests which were fed one fifth of this daily maximum quantity spent 4 or 5 days in the fourth instar and were accordingly fed 18 mites per day for the additional 2 or 3 days of the fourth instar.

When this method of determining subsistence diet was used for the entire larval period, the minimum amount of food at which Stethorus successfully completed its life cycle in the laboratory was found to be one fifth of the

Table 5

AVERAGE AMOUNT OF TIME SPENT BY LARVAE OF PREDATOR SPECIES IN CONSUMING ONE ADULT FEMALE MITE (PARATETRANYCHUS CITRI)*

\begin{tabular}{|c|c|c|c|}
\hline \multirow{2}{*}{ Species of predator } & \multicolumn{3}{|c|}{ Time, in seconds } \\
\hline & Minimum & Maximum & Average \\
\hline Stethorus.... & 135 & 505 & 357.5 \\
\hline Conwentzia. & 30 & 120 & 84.4 \\
\hline 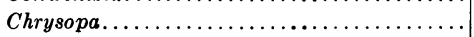 & 5 & 26 & 8.6 \\
\hline
\end{tabular}

* Records obtained by timing five separate feedings (one mite per feeding) of four larvae of each species of predator.

maximum daily feedings shown for larva no. 1 , table 4 . The records for five Stethorus larvae fed this minimum diet are given in table 6 .

The minimum feeding for Chrysopa, determined by the same system, was found to be one tenth of the maximum daily feeding shown for larva no. 3 , table 4. The records for five Chrysopa larvae fed this minimum number of mites are given in table 6.

A comparison of the results of the experiments on minimum and maximum feeding tests reveals the following interesting facts, namely, that Chrysopa and Stethorus larvae can consume a far greater quantity of food than is actually necessary for them to complete their larval development, and that the more they consume daily, the more quickly they complete their larval development. These facts have a direct bearing on the searching capacity of the adult and of the entire population ; for, as has been determined by Roubaud (1917), Flanders (1935), and others, the amount of nutriment received in the larval stages directly affects the size and fecundity of the adult. It is obvious that the more rapid the larval development, the greater will be the number of generations produced in a given time. Furthermore, the greater the population density of the prey, the fewer will be the number of larvae which starve to death. In short, at a high population density of prey, a greater percentage of larvae survive; they complete their development sooner and produce larger, stronger adults which undoubtedly are more fecund. Thus, a variation in the population density of the prey has an immediate and striking effect on the population density of the predator. 
Competition with Other Species of Predators. When several species of predators are searching for a common prey in a given area, there is competition between them for the prey, and, other things being equal, when the prey becomes scarce, that species of predator which can search most efficiently at the lowest prey density will survive in greater numbers for a longer period. This particular type of competition is discussed in detail in a subsequent section (see "Ability to Survive at a Low Prey Density").

Table 6

RECORDS OF MINIMUM FEEDING TESTS OF LARVAE OF TWO PREDATOR SPECIES, STETHORUS AND CHRYSOPA

\begin{tabular}{|c|c|c|c|c|c|c|c|c|c|c|c|}
\hline \multirow{2}{*}{$\begin{array}{c}\text { Larva } \\
\text { number }\end{array}$} & \multicolumn{2}{|c|}{ First instar } & \multicolumn{2}{|c|}{ Second instar } & \multicolumn{2}{|c|}{ Third instar } & \multicolumn{2}{|c|}{ Fourth instar } & \multirow{2}{*}{$\begin{array}{c}\text { Daily } \\
\text { average } \\
\text { of mites } \\
\text { eaten in } \\
\text { last instar }\end{array}$} & \multirow{2}{*}{$\begin{array}{l}\text { Total } \\
\text { days in } \\
\text { larval } \\
\text { period }\end{array}$} & \multirow{2}{*}{$\begin{array}{l}\text { Total } \\
\text { number } \\
\text { of mites } \\
\text { eaten }\end{array}$} \\
\hline & Days & $\begin{array}{c}\text { Number } \\
\text { of mites } \\
\text { eaten }\end{array}$ & Days & $\begin{array}{l}\text { Number } \\
\text { of mites } \\
\text { eaten }\end{array}$ & Days & $\begin{array}{c}\text { Number } \\
\text { of mites } \\
\text { eaten }\end{array}$ & Days & $\begin{array}{c}\text { Number } \\
\text { of mites } \\
\text { eaten }\end{array}$ & & & \\
\hline \multicolumn{12}{|c|}{ Stethorus } \\
\hline $1^{*}$. & 2 & 6 & 2 & . & .. & .. & . & .. & $\ldots$ & .. & $\ldots$ \\
\hline 2 . & 2 & 5 & 4 & 33 & 2 & 35 & 4 & 69 & 17.2 & 12 & 142 \\
\hline 3 & 3 & 10 & 4 & 35 & 4 & 78 & 4 & 58 & 14.5 & 15 & 181 \\
\hline 4. & 3 & 10 & 3 & 27 & 2 & 36 & 4 & 62 & 15.5 & 12 & 135 \\
\hline $5 \ldots$ & 2 & 6 & 3 & 29 & 3 & 54 & 5 & 78 & 15.6 & 13 & 167 \\
\hline \multicolumn{12}{|c|}{ Chrysopa } \\
\hline $1 \ldots \ldots \ldots$ & 8 & 208 & 10 & 441 & 10 & 1,504 & .. & .. & 150.4 & 28 & 2,153 \\
\hline $2 \nmid \ldots \ldots \ldots$ & 8 & 196 & 23 & 1,301 & .. & $\ldots \ldots$ & .. & .. & $\ldots \ldots$ & . & 1,497 \\
\hline $3 \ldots \ldots \ldots$ & 9 & 257 & 10 & 507 & 10 & 1,682 & .. & .. & 168.2 & 29 & 2,446 \\
\hline $4 \ldots \ldots \ldots$ & 7 & 171 & 13 & 696 & 12 & 2,034 & .. & .. & 169.5 & 32 & 2,901 \\
\hline $5 \ldots \ldots \ldots$ & 8 & 233 & 14 & 783 & 11 & 1,833 & .. & .. & 166.6 & 33 & 2,849 \\
\hline
\end{tabular}

* Larva died on second day of second instar.

$\dagger$ Larva died on twenty-fourth day of second instar.

There is, however, another type of competition which is not at all uncommon : it is the competition which exists between different species of predators, when one species of primary predator is attacked by other species of primary predators. According to Nicholson (1933, p. 166) :

The attack of primary predators by other species of primary predators tends to increase the efficiency of the predators in maintaining their own densities, and in controlling the densities of their prey at low values.

The surviving predators are collectively supported by the prey eaten by the attacked predators, as well as by the prey they themselves have eaten. Consequently the density of predators necessary to destroy the surplus of hosts can be supported in a lower density of prey than would otherwise be possible. The predator species share this advantage between them.

Although "the predator species share this advantage between them," it seems logical to assume that if one of the species involved had a distinct ad- 
vantage over the others in this type of competition, it would be a definite asset in the struggle for existence.

The following simple experiments were performed to determine which of the predaceous subjects, if any, most successfully preys on the others.

Three last-instar larvae (one individual of each of the three species of predators) were confined in a small vial. Ten such units were prepared, and the results observed. In every case the Chrysopa larva readily devoured the other two larvae. The test was then repeated, with the Chrysopa larvae omitted. Without exception, the Stethorus larvae attacked and consumed the Conwentzia larvae. In most cases, however, the Stethorus larvae were slow to attack; a period of 16 hours elapsed before the final Conwentzia larva was captured.

Cannibalism. At first consideration it might seem that cannibalism would be detrimental to the species; Nicholson (1933, p. 166), however, theorizes as follows :

Cannibalism increases the efficiency of predators and enables them to maintain their prey at a lower density than would otherwise be possible.

When the surplus predators, instead of dying of starvation, are eaten by other predators of the same species, the survivors obtain at second-hand some of the nutriment provided by the prey that were eaten by the surplus predators. In other words, to the normal area of discovery of a surviving predator is added some fraction of the area of discovery of each of the surplus predators it eats. Thus the efficiency of the average surviving predator is increased by cannibalism, so permitting the steady density of predators to be maintained in a lower density of prey than would otherwise be possible.

By observing a group of different-sized larvae of a single species of predator confined together in a vial, it was readily determined that Chrysopa was quick to attack smaller individuals of its species. By the same method, it was determined that Conwentzia and Stethorus larvae would also attack smaller individuals of their species, but that the attack was generally long delayed, never the quick vicious attack rendered by Chrysopa larvae. It was further determined that Chrysopa larvae of approximately the same size also attack each other, the attacking individual usually being successful. Stethorus and Conwentzia larvae of approximately the same size often starve to death, however, when placed in vials with numbers of their respective species, although an occasional attack is made and the attacked larva consumed.

\section{ABILITY OF PREDATOR SPECIES TO SURVIVE}

Ability to Survive a Critical Period. It would be difficult to determine definitely the most critical period in the life cycle of the predators Stethorus, Conwentzia, and Chrysopa, but it seems reasonable to assume that the time between eclosion and the first feeding is critical for all species, especially under conditions of low population density of the prey. The relative abilities of the three predator species to survive this period were determined by measuring the distance traveled by the newly hatched larva from the time it 
hatched until it died, no food or water being given in the interim. In each case three additional larvae were timed under the same conditions to make sure that the individuals whose distances of travel were traced and measured were more or less representative of the species. The travel patterns are shown in figure $15, a, b$, and $c$. Data presented in table 7 show that Stethorus traveled 134 feet, Conwentzia, 139 feet, and Chrysopa, 702 feet from the time of hatching to the time of death by starvation.
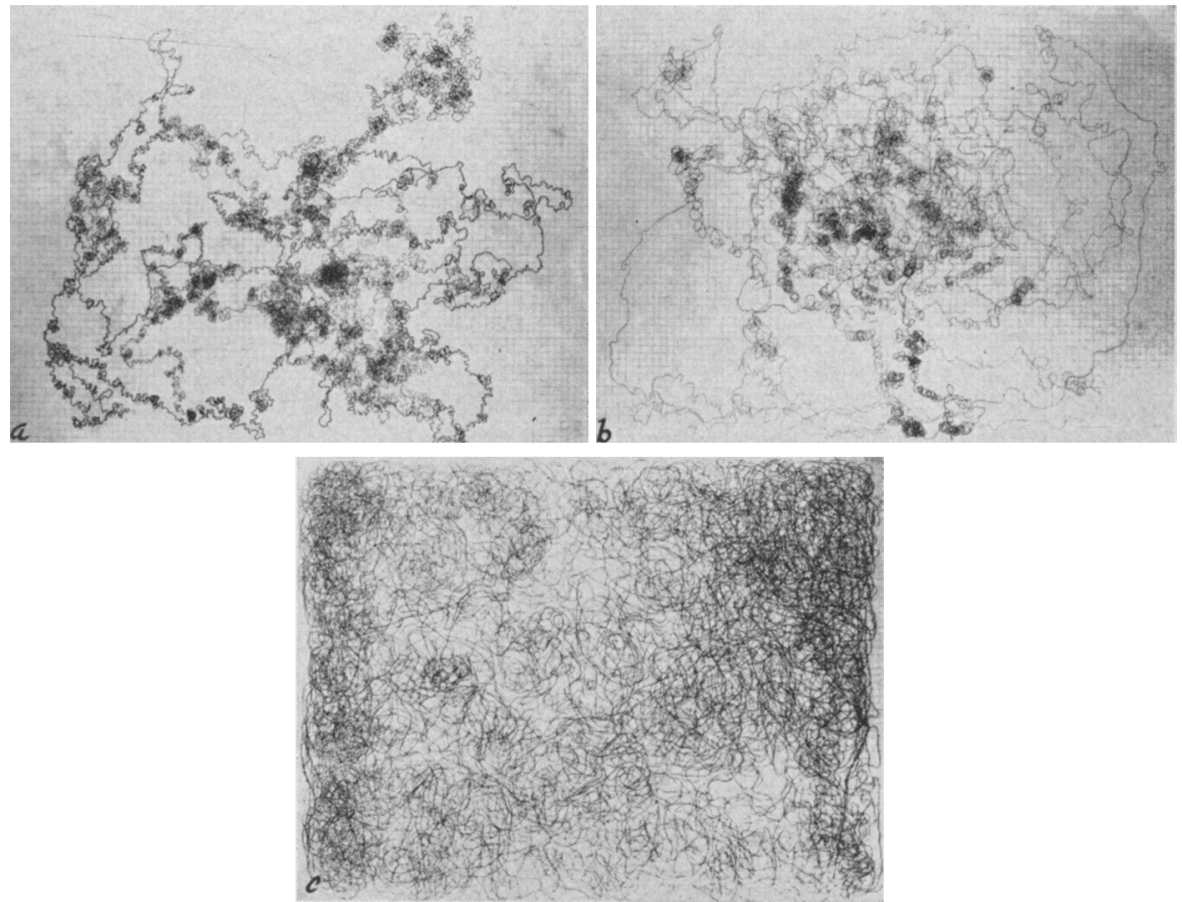

Fig. 15. Searching patterns made by a larva of each of the predator species (a) Stethorus, (b) Conwentzia, and (c) Chrysopa on a Type-I universe (uniform light and topography) from eclosion to death by starvation.

Ability to Survive at a Low Prey Density. The most efficient species of predator from a practical point of view is that species which can destroy the surplus progeny of the prey at the lowest prey population density. Therefore, in evaluating the efficiency of a given species of predator this factor is of primary significance. It is discussed last because under normal conditions it is, in part, a function of all the factors considered in these experiments, with the exception of the ability to destroy large numbers of prey.

The minimum daily subsistence diet of larvae of Chrysopa and Stethorus has already been discussed. The purpose of the present experiment was to determine the minimum population of mites, on the uniform (Type-I) universe, at which each of the predator species is capable of capturing the minimum number of mites required daily. The ability to survive at the lowest prey density is not synonymous with the ability to destroy the surplus 
progeny of the prey at its lowest population density; it is, however, the best measure of this property obtainable by use of larval populations alone.

Since the searching of the predators within a given uniform area has been determined to be purely random, a mathematical formula derived from formulas from the kinetic theory of gases by Stanley (1932) was used to calculate the approximate number of mites that should be distributed at random

Table 7

DISTANCE, DURATION, AND SPEED OF TRAVEL OF NEWLY HATCHED LARVAE OF PREDATOR SPECIES, FROM ECLOSION TO DEATH BY STARVATION

\begin{tabular}{|c|c|c|c|}
\hline Species of predator & $\begin{array}{c}\text { Distance } \\
\text { traveled, } \\
\text { in feet }\end{array}$ & $\begin{array}{c}\text { Duration } \\
\text { of life, } \\
\text { in hours }\end{array}$ & $\begin{array}{c}\text { Average } \\
\text { speed, in } \\
\text { feet per hour }\end{array}$ \\
\hline Stethorus. & 134 & 12.5 & 10.7 \\
\hline Conwentzia. & 139 & 10.1 & 13.8 \\
\hline 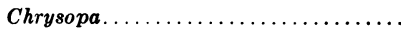 & 702 & 15.25 & 46.0 \\
\hline
\end{tabular}

on the standard universe to allow each species of predator to capture no more than its minimum daily requirements. The formula

$$
N=\frac{\mu \pi \gamma}{\left(\frac{\sigma 1+\sigma 2}{2}\right)^{2}}
$$

was used by Stanley to calculate the probable number of contacts, in a limited amount of flour, between a moving particle (Tribolium adults or larvae) and a stationary particle (Tribolium eggs or pupae), $N$ representing the number of contacts made in a given unit of time, $G$ the volume of space through which the particles are distributed, $\gamma$ the number of stationary particles, $\sigma 1$ their mean diameter, $\sigma 2$ the diameter of the moving particle, and $\mu$ its mean speed.

This formula was modified by Laing (1938) to apply to Trichogramma moving over a limited surface in search of Sitotroga eggs. This modified formula, $N=\frac{\mu \gamma(\sigma 1+\sigma 2)}{G}$, is used in the present calculations, as all of the predaceous larvae considered in these studies were restricted to two-dimensional movement. For purposes of this experiment, $N$ represents the number of contacts in a given unit of time, $G$ the total area available for movement, $\mu$ the mean speed of the predator, $\gamma$ the number of mites used in the experiment, $\sigma 1$ the mean diameter of the mites, and $\sigma 2$ the diameter of the area of perception of the predator.

Values are given or have been determined experimentally for Stethorus and Chrysopa for all parts of the equation except the population density of mites at which the predators can contact their minimum daily requirements. Therefore, the equations are set up with $\gamma$, the number of mites on the universe, as the unknown quantity. Using the average of the minimum number of mites consumed daily in the last instar (calculated from table 6), the values for the various members of the equation to solve for $\gamma$ in the last instar 
of Stethorus are as follows: $N$ (number of contacts per hour), $0.67 ; G$ (area of universe), 336 square inches; $\sigma 1$ (mean diameter of mites), 0.02 inches; $\sigma 2$ (diameter of area of perception of predator), 0.02 inches; and $\mu$ (mean speed of predator), 774 inches per hour. The equation for Stethorus, therefore, is $\frac{774 \times \gamma(0.02+0.02)}{336}=0.67$. When calculated, $\gamma$ (the number of mites on the universe) is found to be 7.2 for an area of 336 square inches, or one mite for 46.7 square inches.

Table 8

OBSERVED NUMBER OF MITES (PREY) CONTACTED BY LARVAE OF PREDATOR SPECIES STETHORUS AND CHRYSOPA FOR GIVEN CALCULATED MINIMUM MITE POPULATION

\begin{tabular}{c|c|c|c|c|c}
\hline \hline Larva number & $\begin{array}{c}\text { First } \\
\text { hour }\end{array}$ & $\begin{array}{c}\text { Second } \\
\text { hour }\end{array}$ & $\begin{array}{c}\text { Third } \\
\text { hour }\end{array}$ & $\begin{array}{c}\text { Fourth } \\
\text { hour }\end{array}$ & $\begin{array}{c}\text { Total } \\
\text { within } \\
\text { 4 hours }\end{array}$ \\
\hline
\end{tabular}

Stethorus (mite population, 1 per 46.7 sq. in.)

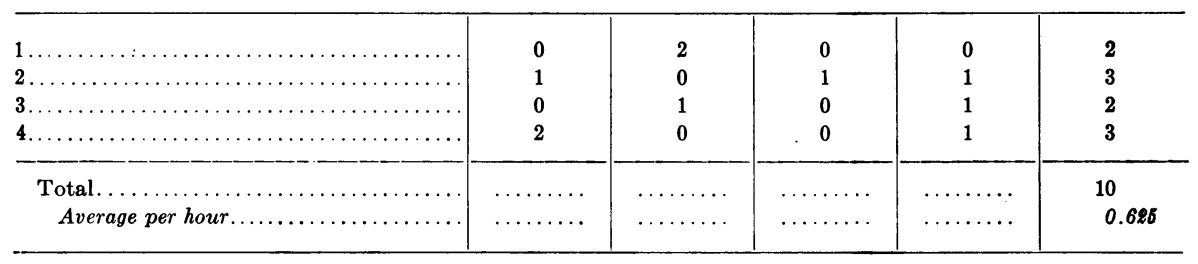

Chrysopa (mite population, 1 per 23.6 sq. in.)

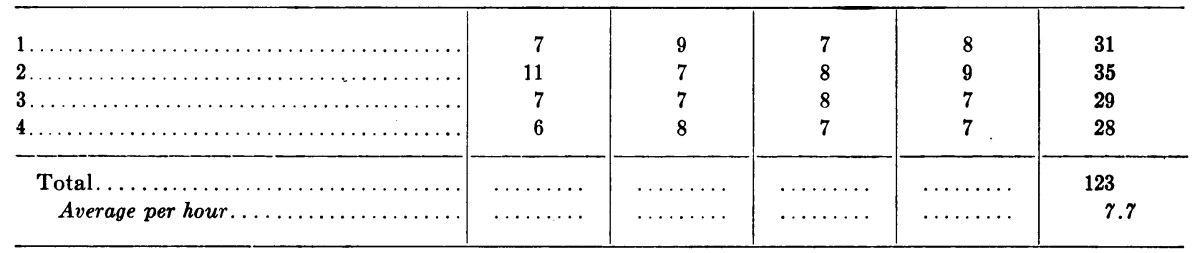

This calculated mite population density was tested by adjusting the size of the universe so that one freshly killed mite per 46.7 square inches could be distributed fairly uniformly over its surface; then a Stethorus larva was placed on the universe and observed for a period of 4 hours. This procedure was repeated four times, using a different larva each time. The results (table 8 ) show that 0.62 contacts were made per hour, instead of the 0.67 contacts calculated. Using these figures $\left(\frac{7.2}{0.62}=\frac{x}{0.67}\right.$, where $\left.x=7.78\right)$, it is found that the observed value for the minimum mite population density is 7.78 in an area of 336 square inches, or one mite per 43.2 square inches, against the expected one mite per 46.7 square inches. The observed value, however, is close to the calculated value and indicates that the preceding experiments have yielded fairly accurate results.

The corresponding values for the various parts of the equation for Chrysopa are as follows: $N$ (number of contacts per hour), 6.8 (calculated from table 6); $G$ (area of universe), 336 square inches; $\sigma 1$ (mean diameter of 
mites), 0.02 inches; $\sigma 2$ (diameter of area of perception of predator), 0.04 inches; $\mu$ (mean speed of predator), 2675 inches per hour. The equation for Chrysopa, therefore, is $\frac{2,675 \times \gamma(0.02+0.04)}{336}=6.8$, and the calculated value for $\gamma$ is 14.24, or one mite for each 23.6 square inches. To test the accuracy of this calculated value, the size of the universe was adjusted to contain one freshly killed mite per 23.6 square inches, and four individual Chrysopa larvae were tested as described above for Stethorus. The observed results of this test (table 8 ) show that 7.7 contacts were actually made by Chrysopa instead of the calculated 6.8. Using these figures $\left(\frac{14.24}{7.7}=\frac{x}{6.8}\right.$, where $\left.x=12.58\right)$, it is found that 12.58 mites, or one mite per 26.7 square inches will suffice, instead of the one mite per 23.6 square inches, as calculated.

Table 9

PREY POPULATION DENSITY (SQUARE INCHES OF UNIVERSE PER MITE) NECESSARY FOR PREDATOR LARVA TO CONTACT AND CAPTURE MINIMUM DAILY FOOD REQUIREMENTS

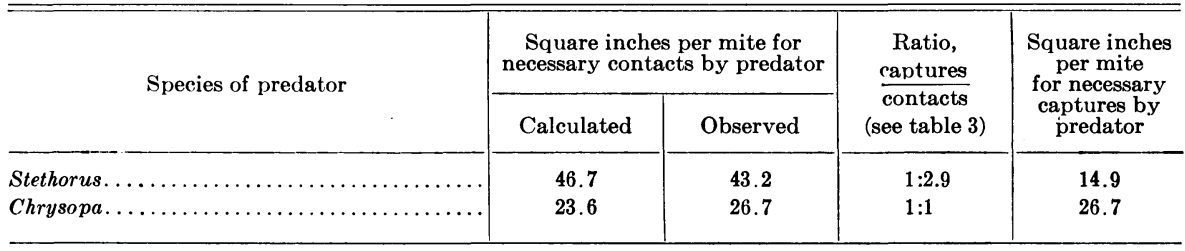

Reference to table 9 will show that, although under conditions of these experiments Stethorus contacts a sufficient number of mites daily to supply its minimum diet at a mite population density of one mite to 43.2 square inches, it actually requires a mite population density of one mite to 14.9 square inches, since the ratio of captures to contacts is $1: 2.9$.

In the final analysis (table 9), under the conditions of these experiments, the relative minimum population densities of the prey at which the predators can survive is one mite per 14.9 square inches for Stethorus, compared with one mite per 26.7 square inches for Chrysopa. It should be noted at this point that, although the lowest prey population density at which Chrysopa completed its development under these test conditions was one tenth of the daily maximum feeding, it could continue to search for a considerable length of time at a much lower population density of mites. For example, larvae fed one twentieth of the maximum number of mites eaten daily, survived for well over a month, spending as many as 30 days in the second instar (death occurring before the third instar was reached) on a food supply of 30 mites a day or 1.25 mites per hour. On the basis of Stanley's modified formula, this number of mites could be captured by Chrysopa larvae at a population density of one mite per 124 square inches. 


\section{FIELD OBSERVATIONS}

The data obtained in the foregoing studies reveal that under controlled experimental conditions individual larvae of Chrysopa are far more efficient as predators of the citrus red mite, at both high and low mite population densities, than are larvae of Stethorus. The relative efficiency of the larvae of Conwentzia in this respect was not fully determined, for these larvae could not be tested under all the experimental conditions. However, the information obtained indicated that the searching ability of Conwentzia would approach that of Stethorus.

General field observations indicate that the results obtained in the laboratory are not necessarily criteria of the relative efficiency of entire populations of these species as predators of the red mite. In fact, field observations made in the course of these studies disclosed that Stethorus was generally a more important factor in reducing high population densities of the citrus red mite than either of the other two species. Both Stethorus and Conwentzia were observed to develop high population densities in relatively pure infestations of the red mite; this population relationship was not observed in the case of Chrysopa. However, Chrysopa larvae developed in large numbers in several groves having rather heavy infestations of mealybugs and aphids; and after the populations of mealybugs and aphids were reduced, presumably by Chrysopa and other natural enemies, fairly large numbers of Chrysopa larvae were still to be found searching the trees for prey. The populations of Chrysopa larvae thus developed were no doubt largely responsible for the fact that the mite population remained surprisingly low in these particular groves for the remainder of the time during which they were kept under observation.

The results of present studies, therefore, do not show which larval predator would be the most efficacious under natural conditions, nor do they indicate the red-mite population densities at which these predators might exert control in the field. Critical studies must be made on the searching capacities of the adults of the predaceous larvae considered in the present work, and also on the searching capacities of entire populations in the field, before their potential values as predators of the citrus red mite can be fully evaluated.

\section{SUMMARY}

Laboratory studies of the searching capacity of the larvae of Stethorus picipes Casey, Conwentzia hageni Banks, and Chrysopa californica Coq., and of their prey, the citrus red mite, Paratetranychus citri (McG.), have revealed that the citrus red mite is positively phototropic and negatively geotropic. The phototropic and geotropic responses of Stethorus correspond very closely to those of the prey, the citrus red mite. The geotropic responses of Chrysopa are in general correlated with those of the prey, although the effect is not so pronounced as with Stethorus; the phototropic responses of Chrysopa are poorly correlated with those of the prey. The geotropic responses of Conwentzia are closely correlated with those of the prey, but the phototropic responses are diametrically opposite.

None of the species of predators studied perceives the presence of the prey on the experimental universe until an actual physical contact has been made. 
The area of perception of larvae of Stethorus and Conwentzia species is 0.02 inches; of Chrysopa it is 0.04 inches.

When searching for food, Stethorus larvae travel at a speed of 64.5 feet per hour, Conwentzia 108.3 feet per hour, and Chrysopa 222.9 feet per hour.

The total area, in square inches, searched in 1 hour by a larva of Stethorus is 15.48, Conwentzia 26, and Chrysopa 107.

The ratio of captures to contacts for the three predator species is as follows : larvae of Stethorus $1: 2.9$, Conwentzia 1:4.5, and Chrysopa $1: 1$.

The area, in square inches, effectively searched in 1 hour by a larva of Stethorus is 5.34, Conwentzia 5.78, and Chrysopa 107.

Chrysopa larvae readily pierce muslin cloth and feed on mites separated from them by the cloth; Stethorus and Conwentzia show no tendency to react in this respect.

The maximum number of mites consumed during the last instar by one of five individuals of each species tested was as follows : Stethorus 190, Conwentzia 319, and Chrysopa 9,580.

The average time, in seconds, required for larvae of the three predator species to consume one mite was as follows : Stethorus 357.5 , Conwentzia 84.4, and Chrysopa 8.6.

Stethorus larvae require a minimum of one fifth of their maximum diet in order to complete the life cycle successfully. Chrysopa larvae can complete the life cycle on one tenth of their maximum diet.

Chrysopa larvae prey readily on larvae of the other two species of predators. Stethorus larvae prey on larvae of Conwentzia but not on those of Chrysopa. Conwentzia larvae do not prey on larvae of the other two species.

All three species of predators are cannibalistic, but Chrysopa shows a much stronger tendency in this respect than either of the other two predators.

When deprived of food and water from eclosion to death, Stethorus larvae will travel a distance of 134 feet, Conwentzia, 139 feet, and Chrysopa, 702 feet.

The searching of these larvae in an area of uniform topography and illumination is random, and their random movement is amenable to mathematical calculation by use of formulas derived from the kinetic theory of gases. Theoretically, Stethorus larvae can complete their development on a prey population density of one mite per 14.9 square inches, and Chrysopa larvae can complete their development on one mite per 26.7 square inches.

It is pointed out that the results of these studies do not demonstrate which of these larval predators would be most efficacious under natural conditions, and that critical studies must be made on the searching capacities of the adults and of the entire population in the field before their values as predators of the citrus red mite can be fully evaluated. 


\section{LITERATURE CITED}

Flanders, S. E.

1935. Host influence on the prolificacy and size of Trichogramma. Pan-Pacific Ent. 11: 175-77.

1945. A barrier for confining crawling organisms. Jour. Econ. Ent. $38: 495$.

LAING, J.

1938. Host-finding by insect parasites. II. The chance of Trichogramma evanescens finding its hosts. Jour. Expt. Biol. 15(3):281-302.

Nicholson, A. J.

1933. The balance of animal populations. Jour. Anim. Ecol. Sup. 2(1) :12s-78.

QUAYLE, H. J.

1912. Red spiders and mites of citrus trees. California Agr. Exp. Sta. Bul. 234:483-530.

Roubaud, E.

1917. Observations biologiques sur Nasonia brevicornis Ashm., chalcidide parasite des pupes de muscides. Bul. Sci. de la France et Belg. 50:425-39.

StanLey, John.

1932. A mathematical theory of the growth of populations of the flour beetle, Tribolium confusum Duv. Canad. Jour. Res. 6:632-71. 

The journal Hilgardia is published at irregular intervals, in volumes of about 600 pages. The number of issues per volume varies.

Subscriptions are not sold. The periodical is sent as published only to libraries or to institutions in foreign countries having publications to offer in exchange.

You may obtain a single copy of any issue free, as long as the supply lasts; please request by volume and issue number from:

\section{Publications Office \\ College of Agriculture \\ Berkeley 4, California}

The limit to nonresidents of California is 10 separate issues on a single order. A list of the issues still available will be sent on request. 